Article

\title{
The Secretome and N-Glycosylation Profiles of the Charophycean Green Alga, Penium margaritaceum, Resemble Those of Embryophytes
}

\author{
Eliel Ruiz-May ${ }^{1,2}$, Iben Sørensen ${ }^{1}$, Zhangjun Fei ${ }^{3,4}$, Sheng Zhang ${ }^{5}$, David S. Domozych ${ }^{6}$ \\ and Jocelyn K. C. Rose ${ }^{1, * \text { iD }}$ \\ 1 Plant Biology Section, School of Integrative Plant Science, Cornell University, Ithaca, NY 14853, USA; \\ eliel.ruiz@inecol.mx (E.R.-M.); is265@cornell.edu (I.S.) \\ 2 Red de Estudios Moleculares Avanzados, Instituto de Ecología A. C., Cluster BioMimic, Carretera Antigua \\ a Coatepec 351, Congregación el Haya, CP 91070 Xalapa, Veracruz, Mexico \\ 3 Boyce Thompson Institute, Ithaca, NY 14853, USA; zf25@cornell.edu \\ 4 U.S. Department of Agriculture-Agricultural Research Service, Robert W. Holley Center for Agriculture and \\ Health, Ithaca, NY 14853, USA \\ 5 Institute of Biotechnology, Cornell University, Ithaca, NY 14853, USA; sz14@cornell.edu \\ 6 Department of Biology and Skidmore Microscopy Imaging Center, Skidmore College, Saratoga Springs, \\ NY 12866, USA; ddomoz@skidmore.edu \\ * Correspondence: jr286@cornell.edu; Tel.: +1-6072554781; Fax: +1-6072555407
}

Received: 10 January 2018; Accepted: 14 March 2018; Published: 21 March 2018

\begin{abstract}
The secretome can be defined as the population of proteins that are secreted into the extracellular environment. Many proteins that are secreted by eukaryotes are $\mathrm{N}$-glycosylated. However, there are striking differences in the diversity and conservation of $\mathrm{N}$-glycosylation patterns between taxa. For example, the secretome and $\mathrm{N}$-glycosylation structures differ between land plants and chlorophyte green algae, but it is not clear when this divergence took place during plant evolution. A potentially valuable system to study this issue is provided by the charophycean green algae (CGA), which is the immediate ancestors of land plants. In this study, we used lectin affinity chromatography (LAC) coupled with mass spectrometry to characterize the secretome including secreted $\mathrm{N}$-glycoproteins of Penium margaritaceum, which is a member of the CGA. The identified secreted proteins and $\mathrm{N}$-glycans were compared to those known from the chlorophyte green alga Chlamydomonas reinhardtii and the model land plant, Arabidopsis thaliana, to establish their evolutionary context. Our approach allowed the identification of cell wall proteins and proteins modified with $\mathrm{N}$-glycans that are identical to those of embryophytes, which suggests that the P. margaritaceum secretome is more closely related to those of land plants than to those of chlorophytes. The results of this study support the hypothesis that many of the proteins associated with plant cell wall modification as well as other extracellular processes evolved prior to the colonization of terrestrial habitats.
\end{abstract}

Keywords: secretome; cell wall proteins; embryophytes; charophycean green algae; $N$-glycosylation

\section{Introduction}

Cells secrete populations of proteins collectively referred to as the 'secretome' for purposes such as maintaining and modulating cell and tissue integrity, regulating the external environment, and defense [1-5]. The composition of the secretome varies among the kingdoms of life and consists of a few hundred up to more than a thousand proteins [3,6-8], with the specific populations being highly dynamic and adaptive to different environments and stress conditions $[3,4,7]$. In this regard, 
the secretome of an organism can reflect a particular habitat including the complexity of the organism's life cycle and its lifestyle [3]. For instance, a significant proportion of the secretome of land plants includes proteins associated with the assembly and remodeling of complex polysaccharide cell walls [9-12], which reflects the importance of cell wall modification during cell growth, differentiation, and responses to different stress conditions. Other sets of proteins contribute to wall reinforcement and the deposition of structural protein frameworks, phenylpropanoid polymers such a lignin or lipid barriers in the cuticle of epidermal cells. Moreover, during pathogen infection, land plants produce large numbers of hydrolytic and other degradative enzymes as well as other defense-related proteins to reinforce the host cell wall and suppress microbial infection $[13,14]$. Notably, much of the land plant secretome is devoted to surviving in a terrestrial environment with its attending challenges of biotic and abiotic stresses and establishing a supportive and structurally plastic, cell wall infrastructure.

In contrast, the secretome of the chlorophyte green alga Chlamydomonas reinhardtii, which lives in an aquatic habitat, is mainly composed of a variety of hydroxyproline-rich glycoproteins (HRGPs), flagellar proteins, and peptidases [15-18]. The HRGPs form a relatively simple cell wall matrix and are also associated with promoting the adhesion of the gametes during mating $[19,20]$. The absence of complex polysaccharides in the cell wall of $C$. reinhardtii mirrors a relative paucity of cell wall associated proteins in its secretome $[17,18,21]$.

A large proportion of the proteins in eukaryotic secretomes are $N$-glycosylated. A post-translational modification (PTM) that exhibits a substantial degree of structural diversity between different kingdoms [22-24]. Much attention has been paid to the N-glycosylation of proteins that are secreted by several microalgae $[17,25]$ in part due to an interest in the potential use of these proteins by the pharmaceutical industry [25]. In this regard, and in contrast to the N-glycan structures of land plants [26], structural studies of cell wall glycoproteins from the red microalgae, Porphyridium sp., revealed the presence of a specific $\mathrm{N}$-glycan structure with internal 6-O-methylated mannose residues and a xylose residue attached to an external mannose residue of the 6-antenna [27]. In addition, structural studies showed that the diatom, Phaeodactylum tricornutum, produces predominantly high mannose type $N$-glycans and less frequently $N$-glycans with $\alpha$-1,3-fucose (Fuc) residues [25]. It has also been reported that sialylated $N$-glycans similar to those commonly found in mammalian glycoproteins are present in C. reinhardtii $[28,29]$. $N$-glycans from $C$. reinhardtii are partially methylated on the outer mannose residues and contain the $\beta-1,2$-xylose residues typically found in the $N$-glycans of land plants [17]. Furthermore, unlike red microalgae, land plants commonly produce extracellular glycoproteins containing complex type $N$-glycans decorated with $\beta-1,2$ xylose and $\alpha-1,3$-fucose [30]. C. reinhardtii diverged from land plants over one billion years ago but has retained many genes of the last common plant-animal ancestor [21] and, accordingly, its $N$-glycosylation machinery shows both differences and similarities to that of land plants. However, little is known about the evolutionary transition where the $\mathrm{N}$-glycan structures commonly found in land plants diverged from typical algal N-glycans (see Figure 1A). To this end, the charophycean green algae (CGA) represent an interesting model since they are considered to be the closest living ancestors of land plants (or embryophytes) and extant examples are likely descendants of the green plants that first colonized terrestrial habitats about 450 million years ago [31-33].

The CGA consists of six main groups including the Charophytales, the Coleochaetales, the Zygnematales, the Klebsormidiales, the Chlorokybales, and the Mesostigmatales of which the three latter are considered to be early diverging and the three former to be later diverging [33]. There is no clear consensus as to which of the later diverging groups was sister to land plants, but the Zygnematales $[34,35]$ of which Penium margaritaceum is a member, has recently been proposed as a strong candidate.

The application of high throughput technologies to study species within the CGA either to identify cell wall genes or to characterize cell wall components has shed light on the evolutionary history of the plant cell wall. For example, analysis of expressed sequence tags and RNA-Seq datasets from CGA species has revealed genes associated with cell wall biogenesis with considerable 
sequence similar to those of land plants [36,37]. Furthermore, the recently published genome sequence of Klebsormidium flaccidum, a member of the CGA, has suggested the presence of genes associated with cell wall formation and modification including those encoding polygalacturonase, cellulose synthase, 3-beta-D-glucan synthase, and pectate lyase [38]. These observations are supported by glycan microarray analysis of extracted cell wall polysaccharides and sugar linkage analysis, which showed that later diverging CGA contain polymers commonly found in embryophytes [37] as well as numerous immunocytochemical studies of diverse CGA species [39-43]. Among the CGA, P. margaritaceum, has shown great potential for fundamental studies associated with cell wall biogenesis $[41,42]$ including the secretion of cell wall proteins. Live cell labeling of P. margaritaceum cells using monoclonal antibodies that recognize polysaccharide epitopes of land plant cell walls also allows the study of cell wall dynamics [41]. An additional feature of P. margaritaceum is that it produces and secretes an extracellular polymeric substance (EPS) that covers the outer surface of the cell wall. This EPS has been associated with establishing biofilm communities and for providing a barrier against biotic or abiotic stress [44-49]. One of the most notable functions of the EPS is protection against desiccation [47], which was likely a key factor for the transition from fresh water to terrestrial environments [39,44-46,49-52]. It is also of note that P. margaritaceum is the only CGA species to date that has been stably transformed and, therefore, could lend itself to functional characterization of genes encoding secreted proteins and those involved in $N$-glycosylation [53].

A

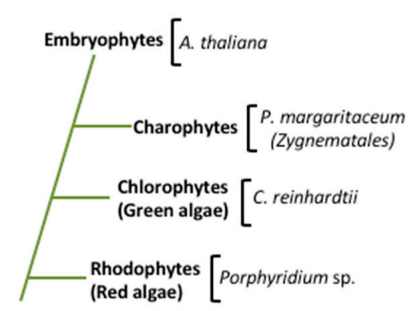

B
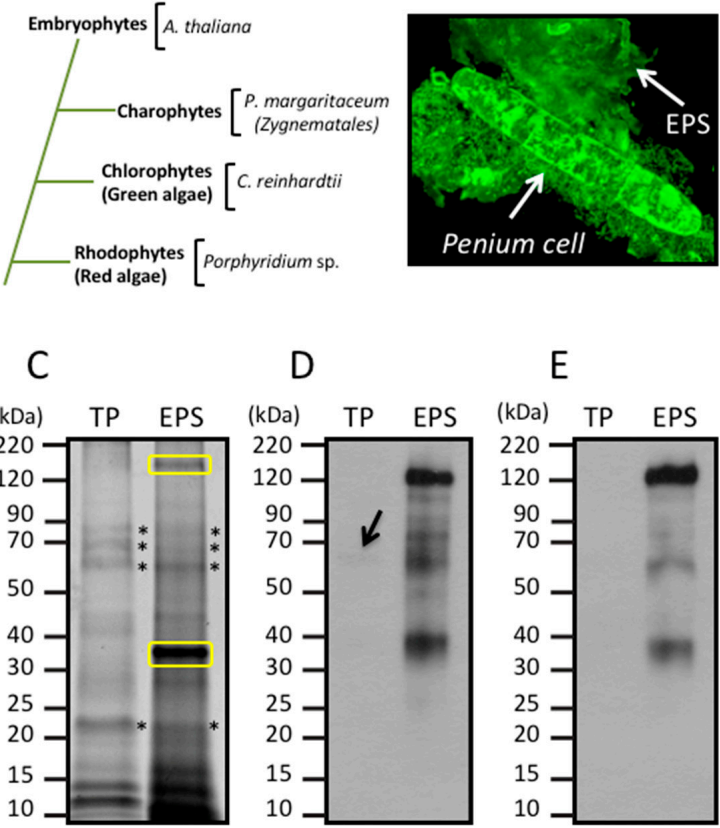

D

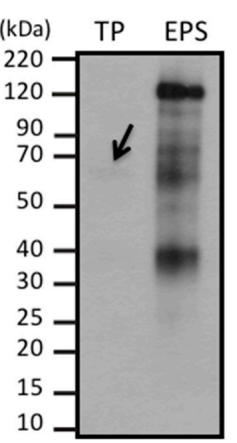

E

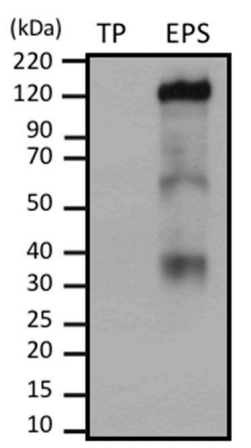

Figure 1. (A) Phylogenetic relationship between Embryophytes, Charophytes, Chlorophytes, and Rhodophytes based on [54] and (B-D) immunological detection of extracellular polymeric substance (EPS), $\beta-1,2$-xylose, and $\alpha-1,3$-fucose in Penium margaritaceum cultures. (B) Live cell immunodetection of EPS using an anti-EPS antibody. The EPS accumulates on the surface of the cell-wall and surrounding milieu, scale bar $=8 \mu \mathrm{m}$. (C) Proteins extracted from P. margaritaceum cells (total protein, TP) or EPS were fractionated by SDS-PAGE and stained with SYPRO Ruby. Asterisks indicate protein bands observed in both TP and EPS. Yellow boxes indicate the densest protein bands in the EPS protein extract. Numbers to the left of each gel show the molecular weight in kDa of the protein markers in the 1D SDS-PAGE. Immunological analysis of TP and EPS extracts using antibodies raised against epitopes of $\beta-1,2$-xylose (D) and $\alpha-1,3$-fucose (E). In (D), the arrow indicates the weak immunodetection of $\beta-1,2-x y l o s e ~ e p i t o p e s$. 
Recently, multi-lectin affinity chromatography (MLAC) has been used for the systematic characterization of the cell wall proteome/secretome of several eukaryotes including the model plants Arabidopsis thaliana and tomato (Solanum lycopersicum) [6,30,55]. However, in contrast to land plants, little is known regarding the secretory pathway of the CGA or whether the pattern of $\mathrm{N}$-glycosylation is similar to that of land plants. However, a comparative bioinformatics study of K. flaccidum has suggested the presence of homologs of many of the genes involved in $\mathrm{N}$-glycosylation in land plants [56]. We hypothesized that characterization of the CGA secretome and structural analysis of the constituent $\mathrm{N}$-glycans might provide insights into the evolution of $\mathrm{N}$-glycosylation and the plant secretome and reveal whether it is more similar to that of the chlorophytes or embryophytes and whether any unique patterns are evident in the CGA. In this study, we used Concanavalin A-based lectin affinity chromatography (LAC) coupled with mass spectrometry to characterize the secretome of P. margaritaceum. We also identified proteins associated with the EPS and determined the structural features of the $\mathrm{N}$-glycans of secreted $\mathrm{N}$-glycoproteins.

\section{Material and Methods}

\subsection{P. margaritaceum Growth Conditions}

Penium margaritaceum Brébisson (Skidmore College Algal Culture Collection) was maintained in sterile liquid cultures of Woods Hole (WH) medium (pH 7.2) [57] at $18 \pm 2{ }^{\circ} \mathrm{C}$ in a photoperiod of $16 \mathrm{~h}$ light $/ 8 \mathrm{~h}$ dark with $74 \mu \mathrm{M}$ photons $\mathrm{m}^{-2} \mathrm{~s}^{-1}$ Photosynthetic Photon Flux of cool white fluorescent light. The cells were sub-cultured every week and cells/culture medium from log-phase cultures (14-21 d old cultures) were harvested for subsequent experiments.

\subsection{Collection of P. margaritaceum Cells and EPS}

Cells were collected in sterile $50 \mathrm{~mL}$ centrifuge tubes and centrifuged for $1 \mathrm{~min}$ at $1000 \times \mathrm{g}$. The supernatants consisting of culture medium containing secreted EPS were collected and stored on ice. The cell pellets were re-suspended in fresh $\mathrm{WH}$, vortexed vigorously for $30 \mathrm{~s}$, and re-centrifuged. This washing step was repeated three times. The supernatants were combined and stored on ice. The cell pellets were combined and used for subsequent protein extractions.

For EPS collection, cell supernatants were placed in sterile $1 \mathrm{~L}$, non-tissue culture treated plastic flasks, and vigorously shaken for $2 \mathrm{~min}$. The supernatants were then centrifuged for $10 \mathrm{~min}$ at $12,000 \times g$. The resultant supernatant contained large floating masses of EPS gel. These masses were collected using a sterile pipette and then combined and used for protein extraction.

\subsection{Algal Protein Extraction and LAC}

Five $\mathrm{mL}$ of concentrated $P$. margaritaceum culture was mixed with $10 \mathrm{~mL}$ of extraction buffer ( $25 \mathrm{mM}$ Tris, $\mathrm{pH} 7,0.2 \mathrm{M} \mathrm{CaCl}_{2}, 0.5 \mathrm{M} \mathrm{NaCl}$, and $20 \mu \mathrm{L} / \mathrm{g}$ fresh weight protease inhibitor cocktail (Sigma-Aldrich, St. Louis, MO, USA)). The cells were then disrupted using a Bead-Beater homogenizer and $0.5 \mathrm{~mm}$ zirconia/silica beads for $5 \mathrm{~min}$ as previously described [58]. The resulting suspension was sonicated 10 times for $10 \mathrm{~s}$ with a sonic dismembrator model 100 (Fisher Scientific, Inc., Pittsburgh, PA, USA) on full power. The suspension was centrifuged at $25,000 \times g$, at $4{ }^{\circ} \mathrm{C}$ for $30 \mathrm{~min}$ and the supernatant was used for enrichment of $\mathrm{N}$-glycoproteins by LAC as previously reported [59]. Briefly, $5 \mathrm{~mL}$ ConA cartridges (Qiagen, Hilden, Germany) were pre-equilibrated with binding buffer (20 mM Tris- $\mathrm{HCl} \mathrm{pH} 7.0,0.5 \mathrm{M} \mathrm{NaCl}, 1 \mathrm{mM} \mathrm{CaCl}_{2}, 1 \mathrm{mM} \mathrm{MnCl}_{2}$, and $1 \mathrm{mM} \mathrm{MgCl}_{2}$ ), at a flow rate of $0.08 \mathrm{~mL} / \mathrm{min}$. The supernatants from the crude protein extracts described above were loaded onto a ConA column using a fast protein liquid chromatography (FPLC) system (Pharmacia Fine Chemicals AB, Uppsala, Sweden) and, after washing the column with three column volumes of binding buffer, the bound proteins were eluted with five column volumes of elution buffer (binding buffer containing $0.5 \mathrm{M} \alpha$-methyl-D-mannopyranoside (Calbiochem, La Jolla, CA, USA)) at a flow rate of $0.75 \mathrm{~mL} / \mathrm{min}$. The eluted glycoproteins were concentrated and the elution buffer was exchanged for 
$100 \mathrm{mM}$ ammonium bicarbonate by using a $5 \mathrm{kDa}$ cutoff centrifugal concentrator (Amicon Ultra-15, Millipore, Billerica, MA, USA) before being lyophilized in a Freezone 6 freeze dry system (Labconco, Kansas City, MO, USA).

\subsection{EPS Protein Extraction}

A total of $50 \mathrm{~mL}$ of EPS was mixed with $100 \mathrm{~mL}$ of extraction buffer and placed on a rocking table for $2 \mathrm{~h}$ at $4{ }^{\circ} \mathrm{C}$ before filtering through a $0.45 \mu \mathrm{m}$ Acrodisc syringe filter (Pall, Newquay Cornwall, UK). The volume of the solution was then reduced to $5 \mathrm{~mL}$ using a $5 \mathrm{kDa}$ cutoff centrifugal concentrator (Amicon Ultra-15, Millipore, Billerica, MA, USA), and the solvent was exchanged three times by adding equal volumes of $100 \mathrm{mM}$ ammonium bicarbonate. The volume was reduced by $50 \%$ using centrifugation according to the manufacturer's instructions. The final sample was frozen in liquid nitrogen, stored at $-80^{\circ} \mathrm{C}$, and lyophilized as above.

The protein concentration was determined using a BCA ${ }^{\mathrm{TM}}$ Assay Kit (Pierce; Rockford, IL, USA) with bovine serum albumin (BSA) as a standard. To visualize the protein composition of the crude extracts, aliquots $(10 \mu \mathrm{g})$ were mixed with 5X Laemmli buffer [60], fractionated on 12\% Tris-glycine SDS-PAGE gels (TGX ${ }^{\mathrm{TM}}$ gels, BioRad; Hercules, CA, USA) and stained with SYPRO ruby (Life Technologies, Grand Island, NY, USA).

\subsection{Trypsin Digestion and N-glycopeptide Enrichment}

Trypsin digestion and $N$-glycopeptide enrichment were carried out as previously described with slight modifications (see Figure S1) [30]. Briefly, N-glycoproteins enriched by LAC and EPS proteins lyophilized samples were dissolved in $8 \mathrm{M}$ urea in $100 \mathrm{mM}$ ammonium bicarbonate, reduced with $10 \mathrm{mM}$ DTT for $1 \mathrm{~h}$, and alkylated with $25 \mathrm{mM}$ iodoacetamide in the dark for $30 \mathrm{~min}$ at room temperature before dilution to a final concentration of $1 \mathrm{M}$ urea with $100 \mathrm{mM}$ ammonium bicarbonate. Proteins were digested with trypsin (Trypsin Gold, Mass Spectrometry Grade, Promega, Madison, WI, USA) at a 1:20 w/w trypsin concentration with a protein ratio for $16 \mathrm{~h}$ at $37^{\circ} \mathrm{C}$. The $\mathrm{pH}$ of the trypsinized samples was then adjusted to 5.0 with $0.1 \%$ trifluoroacetic acid (TFA). EPS tryptic peptides were desalted with C18 solid phase extraction cartridge (Waters, Milford, MA, USA) and dried with a SpeedVac (Thermo Savant, Holbrook, NY, USA) and analyzed by nanoLC-MS/MS. Tryptic peptides from $N$-glycoproteins enriched by LAC were loaded onto a porous graphite carbon (PGC) cartridge (Thermo Scientific, Bellefonte, PA, USA). Subsequently, $1 \mathrm{~mL}$ wash solvent ( $5 \%$ acetonitrile (ACN) in MilliQ water with $0.1 \%$ TFA $(v / v)$ ) was passed through the column. The flow through was recovered and desalted with a C18 solid phase extraction cartridge (Waters, Milford, MA, USA). The bound $N$-glycopeptides were eluted with $1 \mathrm{~mL}$ elution solvent (50\% ACN in MilliQ water with $0.1 \%$ TFA $(v / v)$ ). Both flow through and bound $N$-glycopeptides were dried using a SpeedVac (Thermo Savant, Holbrook, NY, USA) prior to nanoLC-MS/MS analysis.

\subsection{NanoLC-MS/MS (Liquid Chromatography-Tandem Mass Spectrometry) Analysis}

The EPS, PGC bound and flow through samples were analyzed by nanoLC-MS/MS using an LTQ-Orbitrap Velos (Thermo-Fisher Scientific, San Jose, CA, USA) mass spectrometer equipped with a "CorConneX" nano ion source (CorSolutions LLC, Ithaca, NY, USA) using a 10- $\mu$ m analyte emitter (NewObjective, Woburn, MA, USA). The Orbitrap was interfaced with an UltiMate 3000 RSLC system (Dionex, Sunnyvale, CA, USA). Each reconstituted fraction (5 $\mu \mathrm{L})$ was injected onto a PepMap C18 trap column $(5 \mu \mathrm{m}, 300 \mu \mathrm{m} \times 5 \mathrm{~mm}$, Dionex) at $20 \mu \mathrm{L} / \mathrm{min}$ flow rate and then separated on a PepMap C-18 RP nano column $(3 \mu \mathrm{m}, 75 \mu \mathrm{m} \times 15 \mathrm{~cm})$ using a 60 -min gradient from $5 \%$ to $40 \%$ ACN in $0.1 \%$ formic acid (FA) at $300 \mathrm{~nL} / \mathrm{min}$. The Orbitrap was operated in positive ion mode with nanospray voltage set at $1.5 \mathrm{kV}$ and source temperature at $275^{\circ} \mathrm{C}$. The Fourier Transform mass analyzer (FTMA) was calibrated using either the background polysiloxane ion signal $(\mathrm{m} / \mathrm{z} 445.120025)$ as an internal lock mass or the Ultramark 1621 external calibrant (catalog number: 88323, Thermo Fisher Scientific ${ }^{\mathrm{TM}}$ Pierce $\left.^{\mathrm{TM}}\right)$. The instrument was operated in parallel data-dependent acquisition 
(DDA) mode using the FTMA for one survey MS scan at a resolution of 60,000 (FWHM at $m / z$ 400) for the mass range of $m / z$ 375-1800 for precursor ions, which was followed by MS/MS scans of the seven most intense peaks with multiple charged ions above a threshold ion count of 7500 in both LTQ mass analyzer and higher-energy collisional dissociation (HCD)-based FTMA at 7500 resolution. Dynamic exclusion parameters were set at a repeat count of 1 with a $25 \mathrm{~s}$ repeat duration, exclusion list size of 500, 45 s exclusion duration, and \pm 10 ppm exclusion mass width. Collision induced dissociation (CID) parameters were set at an isolation width $2.0 \mathrm{~m} / \mathrm{z}$, normalized collision energy $35 \%$, activation $\mathrm{Q}$ at 0.25 , and activation time $10 \mathrm{~ms}$. The activation time was $0.1 \mathrm{~ms}$ for HCD analysis. All data were acquired with the Xcalibur 2.1 software (Thermo-Fisher Scientific, Waltham, MA, USA).

The nanoLC-MS/MS analysis for characterization of glycosylation sites was performed on an UltiMate3000 nanoLC system (Dionex, Sunnyvale, CA, USA) coupled with a hybrid triple quadrupole linear ion trap mass spectrometer, the 4000 Q Trap (AB SCIEX, Framingham, MA, USA). The tryptic peptides bound to PGC $(5 \mu \mathrm{L})$ were injected. MS data acquisition in a $4000 \mathrm{Q}$ trap was performed using Analyst 1.4.2 software (Applied Biosystems, Foster City, CA, USA) and operated using precursor ion (PI) scan-triggered information-dependent acquisition (IDA) analysis. The precursor ion scan of the oxonium ion $\left(\mathrm{HexNAc}^{+}\right.$at $m / z$ 204.08) was monitored using a step size of $0.2 \mathrm{Da}$ across a mass range of $m / z$ 500-1600 and the parameters were set as previously reported [61]. For IDA analysis, each precursor ion scan was followed by one enhanced resolution scan and the two highest intensity ions with multiple charge states were selected for MS/MS using rolling collision energy (CE) that was set based on the charge state and $m / z$ value of each ion. In the rolling CE setting, high CE and low CE were applied in two separate acquisition methods to gain sequence information regarding both peptides and glycans. We obtained MS/MS spectra with cross-ring fragmentation using high energy. However, the glycan structures reported in this study are based on empirical glycan composition and structure of $N$-glycans reported previously in the literature [61].

\subsection{Data Analysis and Interpretation}

DDA raw data from the Orbitrap was converted into MASCOT generic format (MGF) files using Proteome Discoverer 1.3 (PD1.3, Thermo, Waltham, MA, USA). The subsequent searches were carried out using Mascot Daemon (version 2.3, Matrix Science, Boston, MA, USA) with the following parameters including semi-tryptic protease specificity with one missed cleavage allowed, 20 ppm precursor mass tolerance, 0.8 Da for CID and 0.05 Da for HCD fragment ion mass tolerance with a fixed modification of cysteine carbamidomethylation, and variable modifications of methionine oxidation and asparagine/glutamine deamidation. Mass spectra were used to search a translated in-house unigene databases generated from RNA-Seq data derived from P. margaritaceum cell cultures or PlantGDB (http: / /www.plantgdb.org/). In addition, we used a unigene database generated with sequence reads from Coleochaete orbicularis and Spirogyra pratensis [36]. Only peptides that matched with a MASCOT score above the $95 \%$ confidence interval threshold $(p<0.05$, MASCOT score $\geq 44$ ) were considered for protein identification. In cases where the protein was identified by a single peptide match, the threshold was set at a 99\% confidence interval (MASCOT score $\geq 51$ ). These MASCOT scores resulted in a false-positive identification rate of $4.56 \%$. Only proteins containing at least one unique peptide, which is a sequence that had not been previously assigned to a different protein, were considered.

\subsection{Live Cell and EPS Labeling of P. margaritaceum}

Cells from 14 day old cultures were collected and washed as described above. The pellet was re-suspended in fresh WH, lightly shaken, and then $25 \mu \mathrm{L}$ aliquots of cell suspension were placed in the wells of 10-welled poly-L-lysine coated immuno slides (EMS, Ft. Washington, PA, USA). The cells were allowed to settle for $5 \mathrm{~min}$ and extra growth medium was suctioned off. A $20 \mu \mathrm{L}$ drop of fresh WH was placed on the cells and the slides were allowed to sit under the aforementioned growth conditions (see Section 2.1) for $10 \mathrm{~min}$. The cells were then labeled for immunofluorescence imaging 
with an anti-EPS antibody (anti-Skid8) using a previously described protocol $[39,40]$. The secondary antibody was TRITC-conjugated goat anti-rat antibody (Sigma). After the final wash, a cover slip was mounted onto the slide and cells were observed using an Olympus Fluoview 300 confocal laser scanning microscope.

\subsection{Bioinformatic Analysis}

RNA-Seq raw data is available with the accession number SRP133135 in GenBank (https://www.ncbi.nlm.nih.gov/sra/SRP133135), and unigenes associated with identified proteins are provided with the accession number GGHW00000000.1 (https:/ / www.ncbi.nlm.nih.gov/Traces/wgs/ ?val=GGHW01). Functional annotation of the proteins was carried out using Blast2GO software version 5.0.8 (www.blast2go.com), UniProt functional annotation (http:/ / www.uniprot.org/), and following the procedures outlined in Jamet et al. [62]. Proteins were screened for the predicted presence of an $N$-terminal endoplasmic reticulum (ER) targeting signal peptide (SP) using the Signal P 4.1 program [63]. Those with a predicted SP were analyzed for the presence of predicted $N$-glycosylation sites using the NetGlyc 1.0 server (http:/ / www.cbs.dtu.dk/services/NetNGlyc/). PSORT [64], Target P [65], and PredAlgo [66] were used for determining the predicted subcellular locations of the identified proteins. The TMHMM Server v. 2.0 [67] and SOSUI [68] were used to predict transmembrane domains. For the secretome comparison, we used the complete proteome sequences of the A. thaliana (TAIR10, http:/ / www.arabidopsis.org/ wublast/index2.jsp), Volvox carteri (a chlorophyte, http://genome.gi.doe.gov/pages/blast.jsf?db=Volca) and C. reinhardtii (v4.0, http://genome.jgi-psf.org/pages/blast.jsf?db=Chlre4) proteomes. The mass spectrometry proteomics data have been deposited to the ProteomeXchange Consortium via the PRIDE partner repository with the dataset identifier PXD009123 (https:/ /www.ebi.ac.uk/pride/archive/).

\section{Results}

\subsection{Glycan Structures of P. margaritaceum Extracellular N-glycoproteins}

P. margaritaceum cells actively produce and secrete large amounts of EPS, which can be visualized using polyclonal antibodies specifically raised against this adhesive mucilage. It accumulates on the surface of the cell as well as in the surrounding media/substrate (see Figure 1B). This can be separated from the cells by manually shaking the cultures and subsequent centrifugation. Total protein (TP) from the cells as well as proteins extracted from the EPS were visualized on an SDS-PAGE gel stained with SYPRO Ruby (see Figure 1C). Specific protein patterns were visualized in each sample with two major bands of around $38 \mathrm{kDa}$ and about $180 \mathrm{kDa}$ exclusively observed in the EPS fraction. Other bands of similar molecular weight to each other were observed in both samples (see Figure 1C).

In green plants, $\beta-1,2-x y l o s e(X y l)$ and $\alpha-1,3-$ fucose (Fuc) residues, are commonly found in $N$-glycoproteins [26] (see Figure 1A). In order to determine the presence of these sugar residues in the P. margaritaceum glycoproteins, we carried out an immune detection assay with antisera that recognize Xyl (see Figure 1D) and Fuc residues (see Figure 1E). This resulted in a barely detectable signal in the TP sample (Figure 1D) while a strong signal was seen in proteins extracted from the EPS (Figure 1D,E). This suggests the presence of highly glycosylated $N$-glycoproteins with $\mathrm{Xyl}$ and Fuc residues in the P. margaritaceum EPS sample.

\subsection{Secretome Profiling by LAC and nanoLC-MS/MS}

ConA lectin, which we used as an affinity matrix in this study, specifically binds $\alpha$-mannose $/ \alpha$-glucose on $N$-glycans and it has little cross-reactivity with non-glycosylated proteins. However, it should be noted that since it binds to specific $N$-glycan structures, it does not recognize all glycoproteins [69]. Proteins that bound to the ConA lectin column were digested with trypsin and the resulting glycopeptides enriched with PGC and flow through were analyzed by nanoLC-MS/MS. Peptide sequences derived from the resulting spectra were used to search an in-house P. margaritaceum unigene database derived from RNA-Seq data or the green plant database (PlantGDB, 
http:/ / www.plantgdb.org). We identified 57 proteins using the P. margaritaceum RNA-Seq library while a search of a unigene sequence database of C. orbicularis and S. pratensis [36] allowed the identification of three additional proteins (see Table S1). Computational predictions using Signal P 4.1 indicated that $39(65 \%)$ of the identified proteins contained secretory signal peptides (see Figure 2 and Table S1). In contrast, matching the spectra to the PlantGDB resulted in the identification of 40 proteins of which $10(25 \%)$ were predicted to contain signal peptides (see Figure 2 and Table S2). The P. margaritaceum database was found to be more effective for identifying proteins and subsequent analysis was performed exclusively using protein sequences identified using this database.

Computational analysis also predicted that 30 (50\%) of the identified proteins contained the canonical N-glycosylation N-X-S/T sequon and that 19 of them had more than two glycosylation sites (see Table S1). We used PSORT and Target $P$ to predict the subcellular location of the identified proteins and 39 were predicted to be localized in the secretory pathway while 21 had other predicted subcellular locations (see Table 1 and Table S1). Further functional classification of the identified proteins based on sequence homology using the Blast2GO software (www.blast2go.com), the UniProt functional annotation database (http:/ / www.uniprot.org/), and procedures outlined in Jamet et al. [62] revealed cell wall associated proteins, proteases, and oxido-reductases. Interestingly, homologs of some of the cell wall associated proteins identified in P. margaritaceum have been found in secretome studies of land plants $[6,55,59,70]$. For example, we identified a leucine-rich repeat extensin-like protein 1 (LRX1, Q9LJ64), an arabinogalactan protein (AGP, Q9M7I5), and a fasciclin-like arabinogalactan protein (FLA, G7ILU2), which suggests the presence of these types of cell wall associated proteins prior to the emergence of terrestrial plants. We also identified several protein disulfide isomerase proteins (E3W9C1, Q9FEG4 and Q8VX13, Table S1), which are often annotated as residing in the ER or vacuole.

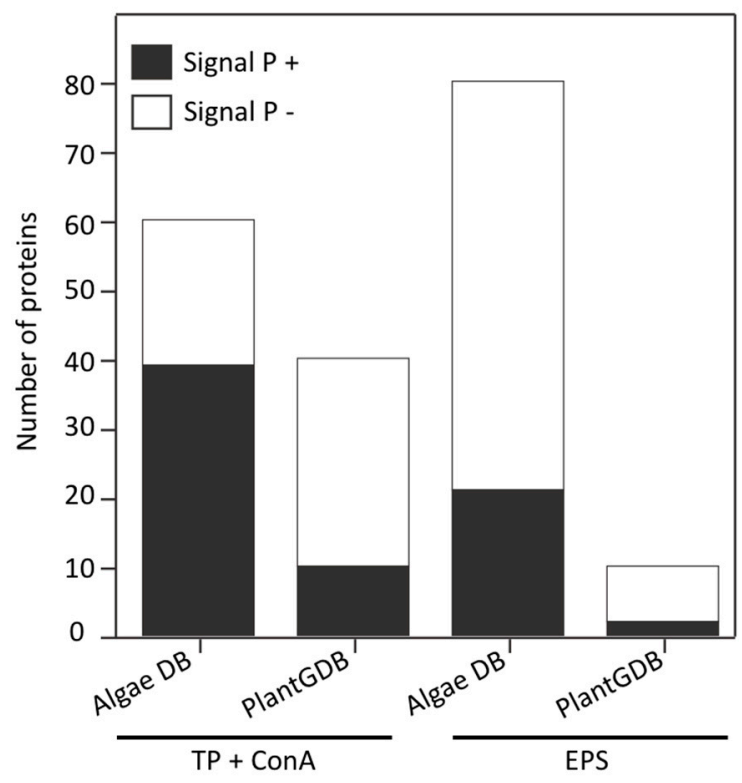

Figure 2. Proteins identified by nanoLC-MS/MS using a Penium margaritaceum, Coleochaete orbicularis, and Spirogyra pratensis database derived from RNA-Seq data or PlantGDB (http:/ / www.plantgdb.org/). The presence of signal peptides was predicted using the Signal P 4.1 program [63]. TP: total proteins extracted from P. margaritaceum cells were used for the enrichment of glycoproteins with Concanavalin A (ConA). The extracellular polymeric substance (EPS) was analyzed without lectin enrichment. 
Table 1. Secreted proteins identified in Penium margaritaceum cultures

\begin{tabular}{|c|c|c|c|c|c|c|}
\hline Unigene ID $^{\mathrm{a}}$ & Name & UAN $^{b}$ & Species & PSORT $^{c}$ & $N$-Glyco ${ }^{\mathrm{d}}$ & Experiment \\
\hline \multicolumn{7}{|c|}{ Cell wall associated proteins } \\
\hline Penium13014-0R & Probable endo-1,3(4)-beta-glucanase Aspergillus niger & A2QBQ3 & Aspergillus niger & Extr & 5 & ConA \\
\hline PU01918-0R & Leucine-rich repeat extensin-like protein 1 & Q9LJ64 & Arabidopsis thaliana & Extr & 3 & ConA \\
\hline Penium10692-1R & Arabinogalactan protein & Q9M715 & Zea mays & Extr & 0 & ConA \\
\hline Penium51331-0F & Fasciclin-like arabinogalactan protein & G7ILU2 & Medicago truncatula & Extr & 3 & ConA \\
\hline Penium05518-1F & Structural constituent of cell-wall, putative & B9S9J6 & Ricinus communis & Extr & 1 & EPS \\
\hline PU11354-0R & Putative uncharacterized protein (Bacterial cellulose synthase subunit) & E6TGN8 & Mycobacterium sp. & Ext & 5 & ConA \\
\hline PU02505-0R & Formin-like protein 2 & Q7XUV2 & Oryza sativa subsp. japonica & Plas & 2 & EPS \\
\hline \multicolumn{7}{|c|}{ Proteolysis } \\
\hline corb_UMD_Coleochaete_c15397_c_s & Peptidase S1 and S6 & A2Q336 & Medicago truncatula & Extr & 3 & ConA \\
\hline Penium $21547-0 \mathrm{~F}$ & Cysteine protease, putative & B9R8S7 & Ricinus communis & Extr & 1 & ConA \\
\hline Penium50713-1F & Intramembrane protease RasP/YluC & A0A0H4WXM9 & Myxococcus sp. & Plas & 1 & EPS \\
\hline corb_UMD_Coleochaete_c16755_c_s & Propeptide PepSY amd peptidase M4 & E8WAR7 & Streptomyces flavogriseus & Extr & 1 & ConA \\
\hline PU17998-0F & Secreted serine protease & B1VSD5 & Streptomyces griseus subsp. griseus & Extr & 3 & ConA \\
\hline PU16802-1F & Cysteine proteinase 2 & Q10717 & Zea mays & Vacu & 2 & ConA \\
\hline PU11399-1F & Membrane protease subunit, stomatin/prohibitin & K6FM44 & Desulfovibrio magneticus & Extr & 1 & ConA \\
\hline Penium04469-1F & Serine carboxypeptidase S28 family protein & D7MUL9 & Arabidopsis lyrata subsp. lyrata & Vacu & 6 & ConA \\
\hline \multicolumn{7}{|c|}{ Oxidoreductases } \\
\hline PU21449-0R & Superoxide dismutase & G9M4K4 & Pogonatum inflexum & Extr & 0 & EPS \\
\hline Penium04764-0F & Ferredoxin thioredoxin reductase catalytic beta chain family & D7L839 & Arabidopsis lyrata subsp. lyrata & Extr & 0 & EPS \\
\hline PU02432-1F & Epimerase/dehydrogenase & D7FJ06 & Ectocarpus siliculosus & Extr & 0 & EPS \\
\hline Penium24287-2R & Protein disulfide isomerase & Q9FEG4 & Triticum durum & Vacu & 1 & ConA and EPS \\
\hline PU08835-1F & Protein disulfide isomerase S-2 & E3W9C1 & Glycine max & ER & 0 & EPS \\
\hline PU15966-1R & Protein disulfide isomerase-like 1-3 & Q8VX13 & Arabidopsis thaliana & ER & 8 & ConA \\
\hline PU13392-0F & Microneme protein, putative & A0A086JBX3 & Toxoplasma gondii & Golg & 8 & ConA \\
\hline PU14524-1R & Glutaredoxin-C4 & Q8LFQ6 & Arabidopsis thaliana & Vacu & 0 & EPS \\
\hline \multicolumn{7}{|c|}{ Miscellaneous } \\
\hline PU00748-1F & GDSL esterase/lipase & Q9M2R9 & Arabidopsis thaliana & Extr & 3 & ConA and EPS \\
\hline Penium53827-1R & Glucosidase II beta subunit & B9SBM9 & Ricinus communis & Extr & 0 & ConA \\
\hline Penium51452-0R & Root cap protein 1 & B6TV36 & Zea mays & Extr & 1 & EPS \\
\hline Penium50864-2R & Alpha amylase, catalytic domain protein & A7A7M5 & Bifidobacterium adolescentis & Chlo & 8 & EPS \\
\hline corb_Contig1457 & Protein phosphatase $2 \mathrm{C}$ & G717K2 & Medicago truncatula & Plas & 1 & EPS \\
\hline PÜ00133-0R & Endonuclease 5 & F4JJL3 & Arabidopsis thaliana & Extr & 4 & ConA and EPS \\
\hline PU14522-2F & PXN-FBPL & Q2LK77 & Xenopus laevis & Vacu & 5 & ConA \\
\hline Penium15798-2R & Alpha/beta-type gliadin & Q41632 & Triticum urartu & Vacu & 0 & ConA \\
\hline Penium42317-1F & Pollen coat oleosin-glycine rich protein & Q6V5D9 & Olimarabidopsis pumila & Extr & 0 & ConA \\
\hline PU21202-1R & BURP domain-containing protein 7 & Q60E34 & Oryza sativa subsp. japonica & Extr & 0 & ConA \\
\hline PU12863-2F & Putative ABC-type transport system & $\mathrm{J} 2 \mathrm{~K} 1 \mathrm{X} 5$ & Rhizobium sp. CF080 & Extr & 1 & ConA \\
\hline PU00769-1R & Endoplasmin homolog & Q9STX5 & Arabidopsis thaliana & ER & 3 & ConA \\
\hline Penium03560-1F & Serine protease inhibitor & Q32TF4 & Argopecten irradians & Extr & 1 & ConA \\
\hline
\end{tabular}


Table 1. Cont.

\begin{tabular}{|c|c|c|c|c|c|c|}
\hline Unigene ID $^{\text {a }}$ & Name & UAN $^{b}$ & Species & PSORT $^{\mathrm{c}}$ & $N$-Glyco ${ }^{d}$ & Experiment \\
\hline PU08363-0R & Carbonic anhydrase & H1XWM8 & Caldithrix abyssi DSM 13497 & Extr & 3 & EPS \\
\hline Penium02868-2F & Peritrophin-1 & E2ADF6 & Camponotus floridanus & Extr & 6 & ConA \\
\hline PU21572-2F & Putative cuticle protein & $\mathrm{COH} 6 \mathrm{H} 4$ & Bombyx mori & Extr & 1 & ConA \\
\hline PU26029-0R & Olfactory receptor 5AK2 & Q8NH90 & Homo sapiens & Plas & 2 & ConA \\
\hline PU32535-2R & Type III secretion protein SpaR/YscT/HrcT & A1TJC4 & Acidovorax citrulli & Plas & 1 & ConA \\
\hline \multicolumn{7}{|c|}{ Unknown function } \\
\hline Penium54960-0F & Uncharacterized protein & G7ME15 & Macaca mulatta & Plas & 12 & ConA \\
\hline PU20188-1R & Putative uncharacterized protein & D7SHJ2 & Vitis vinifera & Extr & 0 & ConA \\
\hline PU23729-1F & Predicted protein & A9TWI4 & Physcomitrella patens subsp. patens & Extr & 8 & ConA \\
\hline PU11719-0R & Putative uncharacterized protein & D8U3A6 & Volvox carteri & Extr & 0 & ConA \\
\hline Penium17901-2F & Putative uncharacterized protein & B6SPS4 & Zea mays & Plas & 0 & ConA \\
\hline Penium42683-0F & Predicted protein & A9RQJ8 & Physcomitrella patens subsp. patens & Extr & 1 & ConA and EPS \\
\hline Penium15957-1F & Uncharacterized protein & L7UB03 & Myхососсиs stipitatus DSM 14675 & Extr & 0 & EPS \\
\hline PU16053-0F & Putative uncharacterized protein & $\mathrm{A} 3 \mathrm{CD} 48$ & Oryza sativa subsp. japonica (Rice) & Plas & 0 & ConA \\
\hline Penium33821-0F & Putative uncharacterized & G7E6T5 & Mixia osmundae & Plas & 3 & ConA \\
\hline PU00167-0R & Putative uncharacterized protein & F1YT29 & Acetobacter pomorum & Plas & 3 & EPS \\
\hline PU08479-1R & Uncharacterized protein & L2G3N6 & Colletotrichum glooosporioides & ER & 0 & ConA \\
\hline
\end{tabular}

${ }^{a}$ Unigenes from in-house RNA-seq database; ${ }^{b}$ UniProt accession number; ${ }^{c}$ Subcellular localization prediction of proteins identified in this study were based on PSORT $\mathrm{s}$ (http://wolfpsort.org). Extr: extracellular, ER: endoplasmic reticulum, Plas: plasma membrane, Vacu: vacuole, Golg: Golgi apparatus, Chlo: chloroplast; ${ }^{\mathrm{d}} \mathrm{N}$-glycosylation sites were predicted using NetNGlyc 1.0 (http:/ / www.cbs.dtu.dk/services/NetNGlyc/). 


\subsection{Identification of Proteins Associated with the EPS}

Proteins extracted from the EPS were digested with trypsin and analyzed by nanoLC-MS/MS using an LTQ-Orbitrap Velos mass spectrometer. The P. margaritaceum database also proved to be the best option for protein identification in the EPS sample (see Figure 2, Tables S3 and S4). We identified 75 proteins using the $P$. margaritaceum database and five additional proteins using unigene sequence from C. orbicularis and S. pratensis. Of these, $21(26 \%)$ were predicted to contain a secretory signal peptide (see Figure 2 and Table S3). Homologs of many of these proteins have been found in the secretome of embryophytes $[6,55,59,70]$ and some of them, such as the structural constituent of cell wall (B9S9J6) and formin-like protein 2 (Q7XUV2), have a direct association with the cell wall (see Table 1 and Table S1) [71]. Several proteins identified in the EPS sample were predicted to contain $\mathrm{N}$-glycosylation sites and four $\mathrm{N}$-glycoproteins identified in the EPS were also identified in the sample of ConA-enriched glycoproteins (Q9FEG4, Q9M2R9, F4JJL3, and A9RQJ8, Table 1). This is consistent with the strong signal observed in the immunological analysis of the EPS protein extracts with antibodies recognizing the (Xyl) and (Fuc) residues of $N$-glycoproteins (see Figure 1D,E). In addition to the secreted proteins, the EPS extracts were shown to contain a high percentage $(74 \%)$ of predicted intracellular proteins, which might reflect cell lysis in culture.

\subsection{Land Plant Cell Wall Protein Homologs in the Cell Wall of P. margaritaceum}

The identification of structural cell wall proteins in P. margaritaceum that are similar to those found in land plants such as arabinogalactan protein (AGP; Q9M7I5), fasciclin-like arabinogalactan protein (FLA; G7ILU2), and leucine-rich repeat/extensin (LRX1; Q9LJ64) indicates some similarities in the structural composition of the primary cell walls of land plants and CGA. AGPs and extensins are glycoproteins that have been proposed to be covalently cross-linked to the polysaccharide matrix in the walls of land plants [72-74]. To confirm the presence and localization of these structural cell wall glycoproteins in P. margaritaceum, we carried out live cell labeling using monoclonal antibodies raised against AGP (JIM8, JIM13, and JIM16) and extensin (JIM20) polysaccharide epitopes [75-78]. Live cell imaging of P. margaritaceum labeled with monoclonal antibodies recognizing AGP epitopes, showed an intense punctuated pattern either on the surface of the cell (see Figure 3A-D) or more loosely associated with the cell wall/EPS (see Figure 3C,D) with more intense signals running along the center of the cell (see Figure 3A,C) around the isthmus zone. This suggests that AGPs are secreted and accumulate on the cell surface and possibly in the extracellular medium of P. margaritaceum. Immune detection of the extensin epitope recognized by JIM20 showed several areas along the cell with a stronger signal (see Figure 3E) and a dense punctuate pattern covering almost the whole cell surface (see Figure 3F). Taken together, the proteomic identification and immune-labeling assays provide strong evidence that AGPs and extensins are present in the primary cell wall of P. margaritaceum, which is consistent with an earlier study based on immunological evidence [37].

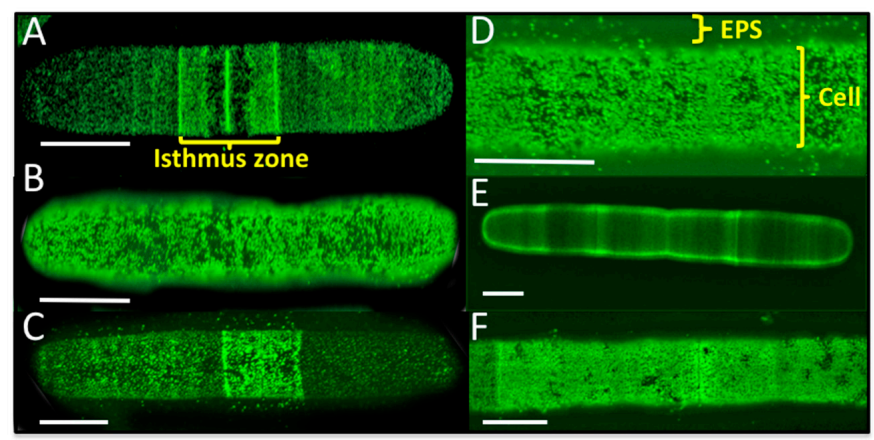

Figure 3. Live cell labeling of Penium margaritaceum cultures using monoclonal antibodies raised against arabinogalactan proteins, JIM8 (A), JIM13 (B), JIM16 (C,D), and extensin JIM20 (E,F), scale bars $=15 \mu \mathrm{m}$. 


\subsection{Structural Determination of N-glycosylation Patterns in the P. margaritaceum Secretome}

Most cell wall associated proteins are highly glycosylated. AGPs, FLAs, and LRX1 are commonly O-glycosylated on serine (S) or hydroxyproline (Hyp) residues [79-81]. In addition LRX1 and FLAs contain the consensus sequence N-X (P)-S/T for N-glycosylation [73]. Our data indicates the presence of putative glycoproteins in the P. margaritaceum secretome. However, since nothing is known about protein glycosylation in any CGA species, we further analyzed our proteins enriched by ConA to determine the structures of the $N$-glycans. Interestingly, we found structures very similar to those found in embryophytes as the MS/MS spectra of the N-linked glycosylation of glycopeptides showed the presence of $\mathrm{Xyl}$ and Fuc residues commonly found in complex $N$-glycans in embryophytes (see Figure 4 and Figure S2) [55,70]. We identified three glycoforms of the peptide MAGNVSVVGK that were distributed over two different charge states by precursor ion scan triggered data-dependent MS/MS analysis with high and low collision energy, which is shown in Figure 4B,C, respectively. This glycopeptide corresponds to the maize root cap protein 2 (Q9ZQT1). These glycoforms had four, eight, and nine mannose residues and all corresponded to the high mannose type (see Figure 4A and Table 2). In addition, at the same elution time, we found a second N-glycopeptide (GSQLNGTYA) with four glycoforms that contained either Xyl or Fuc or both residues (see Figure 4A). These glycoforms corresponded to the receptor of activated protein kinase C1 (Table 2, A8J8Y1). Six additional N-glycan structures with $\mathrm{Xyl}$ and Fuc residues were identified, but their corresponding peptide sequences could not be resolved (see Table 2 and Figure S2). In addition, the low concentration of $N$-glycoproteins in the EPS did not allow for structural determination of any $N$-glycans. However, the combination of immune-labeling (Figure 1D,E) and MS analysis of the enriched N-glycoprotein samples (see Figure 4) strongly indicate that $\mathrm{N}$-glycans from $P$. margaritaceum commonly contain $\mathrm{Xyl}$ and Fuc residues.

Table 2. Endogenous N-glycopeptides and N-glycans identified from Penium margaritaceum cultures.

\begin{tabular}{|c|c|c|c|c|c|c|c|}
\hline Unigene & Protein & UAN $^{a}$ & E-Value & Species & Peptide & $\begin{array}{l}\text { Pep Mass } \\
{[\mathbf{M}+\mathbf{H}]^{+}}\end{array}$ & $\begin{array}{l}N \text {-Glycan } \\
\text { Structures }\end{array}$ \\
\hline \multirow[t]{3}{*}{ PU00576-0F } & $\begin{array}{l}\text { Receptor of } \\
\text { activated protein } \\
\text { kinase } C 1\end{array}$ & A8J8Y1 & $4 \times 10^{-26}$ & $\begin{array}{l}\text { Chlamydomonas } \\
\text { reinhardtii }\end{array}$ & GSQLNGTYA & 910.32 & \\
\hline & & & & & & 961.32 & \\
\hline & & & & & & 687.52 & \\
\hline \multirow[t]{5}{*}{ PU00894-1F } & Root cap protein 2 & Q9ZQT1 & $3 \times 10^{-11}$ & Zea mays & MAGNVSVVGK & 771.48 & \\
\hline & & & & & & 815.40 & \\
\hline & & & & & & 815.40 & \\
\hline & & & & & & 815.40 & \\
\hline & & & & & & 815.48 & \\
\hline
\end{tabular}

${ }^{\mathbf{a}}$ UniProt accession number; ${ }^{\mathbf{b}}$ Glycan structures were manually determined as outlined in material and methods. 
A

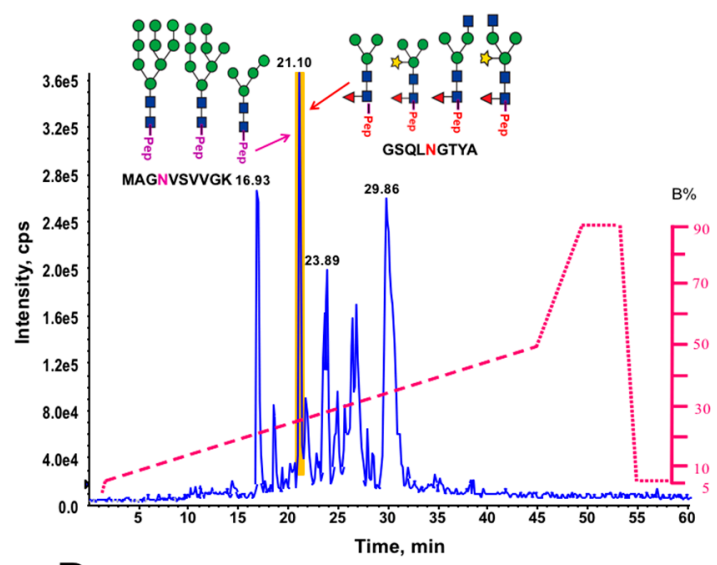

B

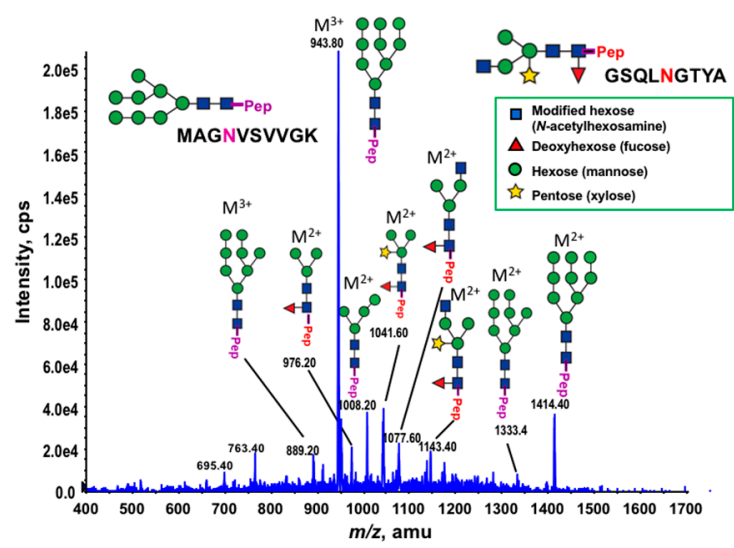

C

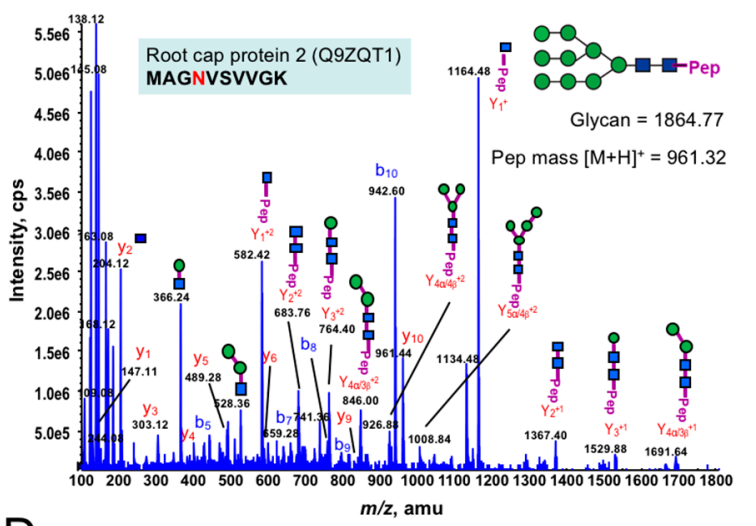

D

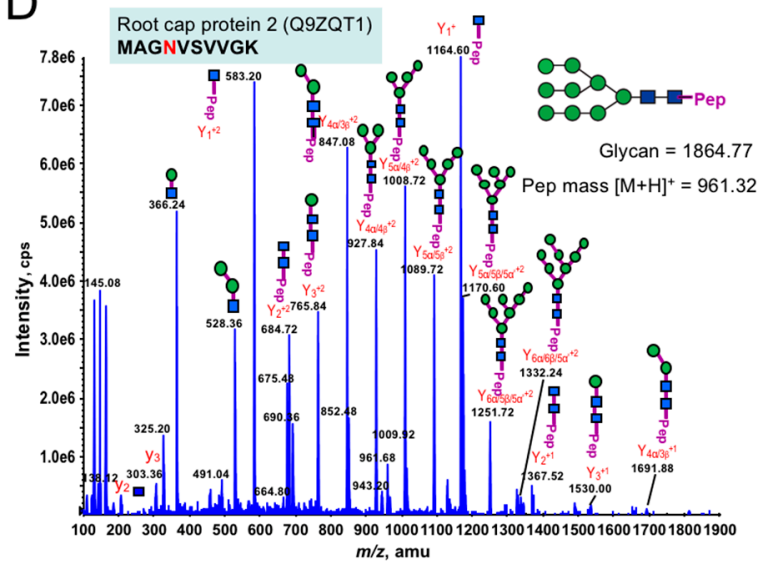

Figure 4. Identification of $\mathrm{N}$-linked glycopeptides from Penium margaritaceum cultures by precursor ion scan triggered data-dependent (PI-IDA) MS/MS analysis. (A) A base peak chromatogram of an LC-MS precursor ion scan (on $m / z+204$.08) triggered IDA for enriched tryptic glycopeptides from P. margaritaceum proteins. Pep in purple and red indicates glycoforms associated with MAGNVSVVGK and GSQLNGTYA, respectively. (B) A representative MS spectrum acquired from a peak eluted at $21.1 \mathrm{~min}$ (see Figure 4A). The spectrum shows a typical "high mannose" and "complex type" $N$-glycan including pentose ( $\beta-1,2-x y l o s e)$ and/or deoxyhexose ( $\alpha-1,3$-fucose) linked to the core $\mathrm{Man}_{3} \mathrm{GlcNAc}_{2}$ structure. (C) An MS/MS spectrum of an $m / z 942.69^{3+}$ ion, which reveal a "high mannose" $N$-linked glycopeptide (MAGNVSVVGK) by using high energy fragmentation (at CE 52). The high energy CID fragmentation yielded a complete $y$-ion/b-ion series along with many $y$-ion series (up to four mannose residues), which resulted in confident identification of the peptide MAGNVSVVGK from root cap protein 2 (Q9ZQT1) containing nine mannose residues. (D) An MS/MS spectrum of same $\mathrm{m} / z 942.69^{3+}$ ion using low energy fragmentation (at CE 34) yielded a complete y-ion series allowing the confident determination of the glycan structure (as a nine-mannose "high mannose" glycan) in the glycopeptide MAGNVSVVGK from the root cap protein 2 (Q9ZQT1).

\subsection{The P. margaritaceum Secretome and N-Glycosylation Patterns Are Closely Related to That of Embryophytes}

The proteins identified in the P. margaritaceum secretome were used in a BLAST search against the proteome sequences of $A$. thaliana, V. carteri, and C. reinhardtii. Most of the proteins identified in P. margaritaceum had homologs encoded in the A. thaliana genome. However, in contrast, we only observed 17 and 16 protein homologs of the P. margaritaceum proteins in $V$. carteri and C. reinhardtii, respectively (see Table S5). The $P$. margaritaceum disulfide isomerases (Q9FEG4 and E3W9C1) have functionally annotated homologs in A. thaliana (Q9XI01 and O22263), V. carteri (Q9SBN2 and Q9SBN2), and C. reinhardtii (O48949 and A8IHI1, Table S5) while only one homolog of the proteases identified 
in P. margaritaceum was found in V. carteri (D8U6V0) and C. reinhardtii (A8I5R9). Even though these proteins from $V$. carteri and C. reinhardtii have not yet been functionally annotated, they are predicted to contain a domain of the papain family of cysteine proteases. Similarly, the homologs of LRX1 (Q9LJ64) found in V. carteri (D8UG11) and C. reinhardtii (A8J9P5) were computationally predicted to contain a leucine-rich repeat domain (LLR_8). In contrast, FLA (G7ILU2), superoxide dismutase (G9M4K4), GDSL esterase/lipase (Q9M2R9), a probable endo-1,3(4)-beta-glucanase (A2QBQ3), and a root cap protein (B6TV36) did not have homologs in either V. carteri or C. reinhardtii (Table S5).

Comparative analyses of the secretome of $C$. reinhardtii determined with $N$-Glyco-filter-aided sample preparation (FASP)-ConA [17] and those of P. margaritaceum and A. thaliana obtained by LAC-ConA [70], revealed striking differences in the proportion of cell-wall associated proteins (see Figure 5). The $C$. reinhardtii secretome contained a small proportion of predicted cell wall associated proteins (3\%) compared to P. margaritaceum and A. thaliana, which had $18 \%$ and $34 \%$, respectively (see Figure 5). Proteins classified as oxido-reductases and proteins associated with signaling were observed in a similar proportion in the secretome of P. margaritaceum and A. thaliana (see Figure 5) while proteins functionally classified as proteases were present in similar proportions in all secretomes analyzed in this study (see Figure 5). Our data suggests that $P$. margaritaceum and embryophytes not only share similar cell wall structural features [37] but also have similar secretomes.
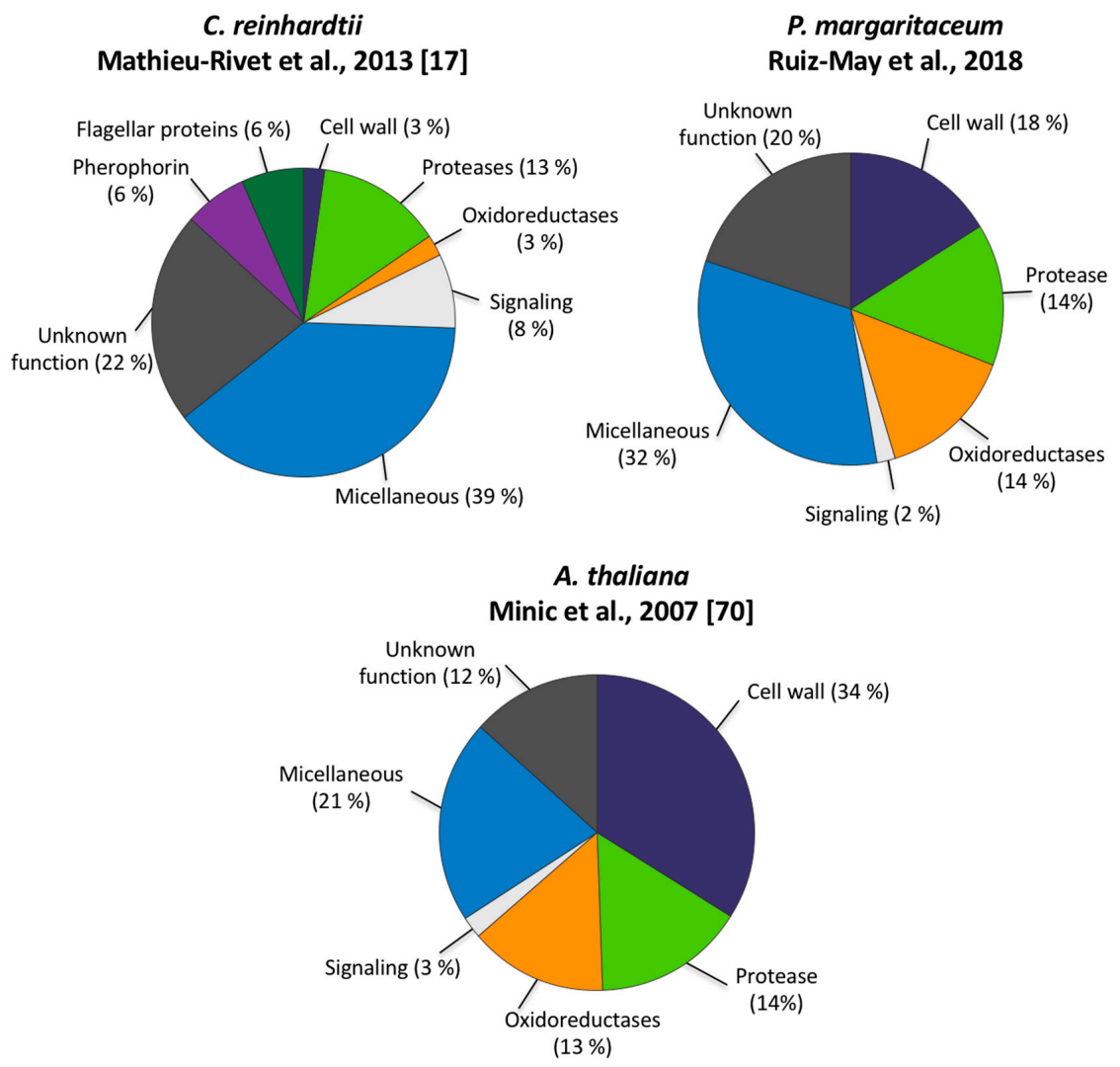

Figure 5. Comparison of the secretomes of Chlamydomonas reinhardtii, Penium margaritaceum, and Arabidopsis thaliana. Secreted proteins analyzed in the C. reinhardtii and A. thaliana secretome were enriched using $N$-Glyco-filter-aided sample preparation (FASP)-ConA and ConA-based lectin affinity chromatography (LAC), respectively $[17,70]$. These proteins were functionally classified using the Blast2Go software (www.blast2go.com) and UniProt functional annotation (http:/ / www.uniprot.org/), according to Jamet et al. [62].

We further analyzed our results by comparing the structural features of $N$-glycans in P. margaritaceum to those in C. reinhardtii [29] and land plants [70] based on the MS analysis (see Figure 6 
and Figure S2). The $N$-glycans of P. margaritaceum were found to contain sugar residues similar to those found in the $N$-glycans of embryophytes such as the $\beta-1,2$-xylose and $\alpha-1,3$-fucose residues. In $P$. margaritaceum, we determined the presence of high-mannose, complex, and paucimannose structures (see Figure 6) with the frequent occurrence of $\beta-1,2-x y l o s e$ and $\alpha-1,3$-fucose residues in the complex and paucimannose structures. Recent studies indicated that $C$. reinhardtii $N$-glycans contain $\beta-1,2$-xylose residues and that the $\alpha-1,3$-fucose residues are present in small proportions and carry one additional xylose residue on the outermost mannose residues [17] (see Figure 6). Additionally, structural features including the tetra-antennary structure and the sialic acid residues characteristic of the mammalian $N$-glycans are present in the structures of the $N$-glycans of $C$. reinhardtii. Since we did not detect these in P. margaritaceum (see Figure 6), our data are consistent with the P. margaritaceum secretome and $N$-glycosylation patterns being more closely related to those of embryophytes.

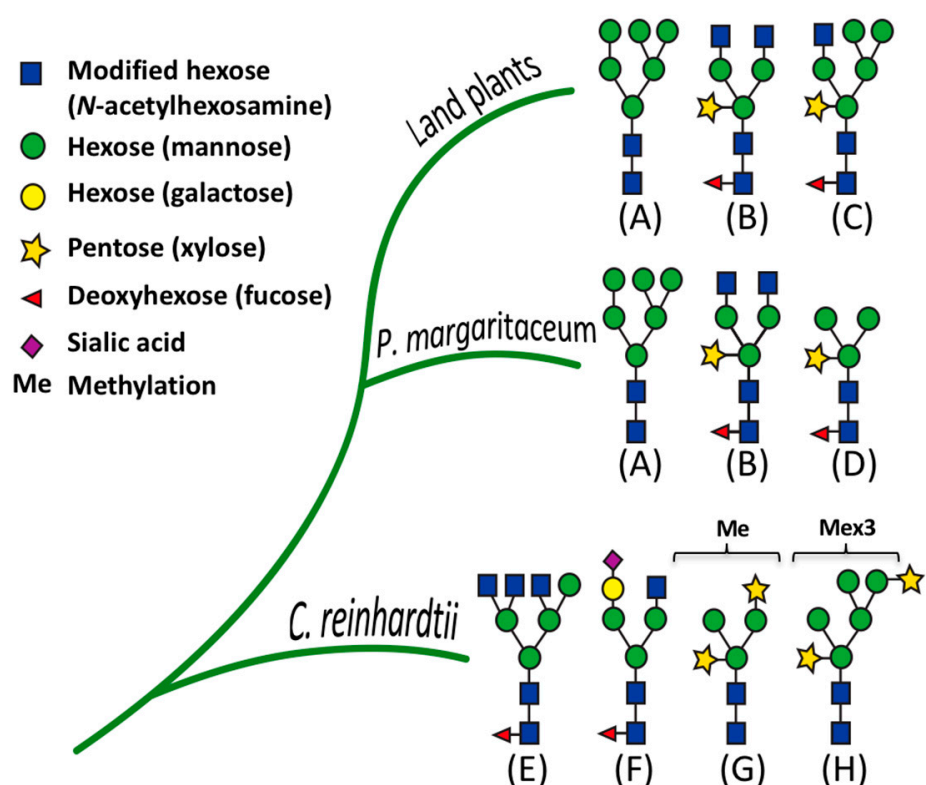

Figure 6. Comparison of the structures of $\mathrm{N}$-glycans identified in Chlamydomonas reinhardtii, Penium margaritaceum, and land plants (embryophytes). (A) high mannose, (B) complex, (C) hybrid, (D) paucimannose, (E) tetra-antennary, (F) sialylation. $(\mathbf{G}, \mathbf{H})$ correspond to N-glycans with an additional xylose residue attached to the outermost methylated mannose residues.

\section{Discussion}

\subsection{Proteomic Analysis of P. margaritaceum Using an RNA-Sequence Database as Reference}

Extensive and accurate genome sequence information provides a platform for effective proteome profiling studies and this has previously limited the application of proteomic technologies to model plants with sequenced genomes. However, the increasing availability of cDNA sequences from different organisms as well as next generation sequencing are providing access to transcriptome information at a rapidly declining cost $[82,83]$. This has expanded the options for systematic identification of proteins even in species with only draft genome sequences and those with no genomic information at all. In our present study, we were able to identify more proteins using a P. margaritaceum RNA-Seq based database rather than by searching the PlantGDB. This is consistent with previous studies reporting the value of a species-specific database for protein identification [82,84-86]. However, the numbers of identified peptides per protein were low in our analyses. It is known that secreted proteins are heavily decorated with multiple post-translational modifications (PTMs) including different types of glycosylation ( $N$-linked and O-linked, C-mannosylation, and glycosylphosphatidylinositol anchors) $[87,88]$ and the P. margaritaceum secretome may contain multiple PTMs that could increase the complexity of mass spectra, which resulted 
in fewer matches. However, future studies will help determine whether a more complete DNA sequence database will further enhance protein identification.

We carried out an in silico analysis of the subcellular location of identified proteins in P. margaritaceum using four different bioinformatic tools including Signal P [63], PSORT [64], Target P [65], and PredAlgo [66]. The latter was designed specifically for prediction of protein subcellular location in green algae [66]. This software showed significant improvements in the capacity to discriminate between chloroplast and mitochondrial proteins, but it did not enhance the signal peptide prediction compared to other prediction programs [66]. However, using PredAlgo for the prediction of subcellular proteins in P. margaritaceum resulted in fewer hits (see Table S1). In addition, well-known cell wall proteins such as FLA (G7ILU2) and GDSL esterase/lipase (Q9M2R9) were predicted to be chloroplast localized (see Table S1). We, therefore, used SignalP 4.1 [63] to predict the presence of signal peptides and PSORT [64] as well as Target P [65] for protein subcellular location of identified protein sequences. Most of the proteins enriched by ConA affinity were predicted to be secreted (see Figure 2), which is in agreement with previous report [30] and highlights the value of LAC as a strategy for secretome analysis.

\subsection{The Secretome of P. margaritaceum is Closely Related to that of Embryophytes}

LAC has been used in several analyses of the secretome of land plants $[30,59,70]$. In this study, we identified several cell wall associated proteins in the P. margaritaceum secretome that have also been found in studies of embryophyte cell walls using LAC (see Table 1). We used monoclonal antibodies against land plant AGP glycans and extensin to verify that these types of proteins are present in not only the P. margaritaceum cell wall but also in the EPS. Interestingly, immunodetection of extensin epitopes (JIM20, Figure 3E) showed the presence of multiple transverse bands on the cell wall, which is similar in appearance to banding patterns observed in P. margaritaceum cells labeled with ConA [41]. Furthermore, these bands resemble the bands of pectic homogalacturonan (HG) that are present during expansion of the cell wall of pollen tubes in land plants $[89,90]$ and we hypothesize that there may be an interaction between extensin and pectin, which is suggested for sugar beet cell walls [91]. Immune-detection of AGP epitopes showed a dense punctuation in the cell wall and EPS (see Figure 3A-D), which is in agreement with studies in A. thaliana where two AGP protein isoforms were identified in both the culture media and cell wall of suspension culture cells [73]. Another interesting finding from this previous study was that the O-glycans of the AGPs were covalently cross-linked to the matrix of hemicellulose and pectic polysaccharides. This close association between AGPs and cell wall polymers was suggested to explain the modification of cellulose deposition and biochemical properties of the cell wall when AGP gene expression was altered [92-95]. It is possible that similar processes occur in P. margaritaceum.

Taken together, the identification of proteins known to be present in the cell wall of land plants (see Table 1), localization of AGP and extensin epitopes in the wall and EPS of P. margaritaceum (see Figure 3), and comparative bioinformatic analyses of green plant taxa (see Figure 5 and Table S4) suggests that the cell walls of P. margaritaceum and land plants have considerable structural and functional similarities. Similarities in their secretomes are also apparent. For example, proteases and proteins related to oxidation-reduction were found in similar proportions in the secretomes of P. margaritaceum compared to A. thaliana (see Figure 5). We note that protein disulfide isomerase S-2 (E3W9C1), protein disulfide isomerase-like 1-3 (Q8VX13), and endoplasmin homolog (Q9STX5) have a predicted localization in the ER and have annotations related to the biological processes of 'protein folding' (GO:0006457) and 'response to endoplasmic reticulum stress' (GO:0034976). Although some of the proteins we identified such as E3W9C1 are not predicted to be extracellular, their presence in the secretory system provides a pathway by which they might may ultimately exit the cell as part of the massive secretory process/bulk flow that is evident in P. margaritaceum. However, we note that cell lysis cannot be ruled out so these data await confirmation using orthogonal techniques. 


\subsection{The EPS is Tightly Associated with the Cell Wall in P. margaritaceum}

It has been suggested for several organisms that the EPS plays an important role in biofilm development, adhesion, gliding, and interaction with other organisms and protection against desiccation [39,40,47,96]. P. margaritaceum produces significant amounts of EPS, which covers the outer surface of the cell and compositional analyses of the EPS in P. margaritaceum showed similar monosaccharides to those found in the cell wall of land plants in an atypical ratio [39,96]. Molecular characterization of the EPS of bacteria and other microorganisms has identified not only polysaccharides but also proteins, nucleic acids, and lipids [47]. In agreement with earlier studies, we detected proteins that are entirely extracellular as well as those that have domains that are located in the plasma membrane (see Table 1) and the cytosol (see Table S3) in the EPS of P. margaritaceum. To highlight one example, formin-like protein 2 (Q7XUV2) has been associated with actin-related processes such as actin nucleation, which polarized cell expansion and signaling [97,98]. It was shown that formin 1 from $A$. thaliana (AtFH1) forms a bridge from the actin cytoskeleton across the plasma membrane and that its extracellular domain is anchored in the cell wall [71]. These interconnections may be important in actin remodeling during cell growth or expansion or under stress conditions $[97,98]$. In addition, it was recently suggested that AtFH14 might regulate actin dynamics through association with profilin [98]. Interestingly, we also identified profilin proteins (Q9XF40 and Q95VF7, Table S3) in the EPS fraction. The detection of both formin-like protein 2 and profilin proteins is consistent with a similarly close association between the cytoskeleton and extracellular matrix of $P$. margaritaceum.

\subsection{N-Glycosylation Patterns Are Conserved between P. margaritaceum and Land Plants}

$N$-Glycosylation is widespread in different kingdoms with multiple $N$-glycan structural variants [24]. However, their structural variation during plant evolution is not well understood. Given that the CGA are located at a pivotal evolutionary point, we hypothesized that an analysis of the P. margaritaceum glycoproteome could provide insights into the evolution of $N$-glycosylation. We found that the $N$-glycans from $P$. margaritaceum have identical structural features to those of land plants and that their structure corresponded to the high mannose, complex, and paucimannosidic types containing $\beta-1,2-x y l o s e(X y l)$ and $\alpha$-1,3-fucose (Fuc) residues linked to the core $\mathrm{Man}_{3} \mathrm{GlcNAc}_{2}$. More than two decades ago, analysis of $N$-glycans from the sexually-induced glycoprotein pheromone of $V$. carteri suggested the presence of Xyl residues and the absence of Fuc residues [99]. However, this has not yet been confirmed by high accuracy mass spectrometry analysis. C. reinhardtii N-glycans have $\mathrm{Xyl}$ and Fuc residues $[17,29]$, but they also have features that distinguish them from land plant $N$-glycans such as the partial methylation of the external mannose residues, the presence of additional Xyl residues on the outermost Man residues, and the presence of sugar features similar to those found in $N$-glycans of mammals $[17,29]$. We note that most of the studies mentioned above were carried out with different mass spectrometry platforms and sample preparation strategies. For instance, previous reports have suggested the occurrence of sialic acid in the N-glycan structures of C. reinhardtii [28,29] while a more recent report found it not to be present [17]. Therefore, corroboration of particular features of $\mathrm{N}$-glycan structures is important while taking advantage of multiple MS fragmentation methods and enrichment approaches [26,100].

We conclude that $N$-glycosylation in P. margaritaceum is more closely related to that of embryophytes than to that of chlorophytes and our data provide evidence of the conservation of 'land plant-like' $N$-glycosylation over at least the last 450 million years. Additional analysis of the $N$-glycan structures from both later diverging chlorophytes and earlier diverging charophytes will presumably further resolve the timeline of plant $N$-glycosylation evolution.

Supplementary Materials: The following are available online at http://www.mdpi.com/2227-7382/6/2/14/s1. Figure S1: proteomic pipeline used in this study, Figure S2: MS/MS spectra of endogenous N-glycopeptides. The $N$-glycan structures were determined manually. The symbol nomenclature for glycan representation is according to [54], Table S1: Proteins identified following Concanavalin A enrichment using a Penium margaritaceum 
RNA-Seq translated database, Table S2: Proteins identified following enrichment with Concanavalin A using the green plant database (http:/ / www.plantgdb.org/), Table S3: Proteins identified in the extracellular polymeric substance (EPS), using a P. margaritaceum RNA-Seq translated database, Table S4: Proteins identified in the extracellular polymeric substance (EPS) using the green plant database, Table S5: Proteins identified in the P. margaritaceum secretome used in a BLAST search against the genome database of Arabidopsis thaliana (http:/ / www.arabidopsis.org/wublast/index2.jsp), Volvox carteri (http://genome.jgi.doe.gov/pages/blast.jsf? $\mathrm{db}=$ Volca1) and Chlamydomonas reinhardtii (http://genome.jgi-psf.org/pages/blast.jsf?db=Chlre4).

Acknowledgments: D.S.D. and J.K.C.R. were supported by grants NSF-MCB 1517345 and 1517546 from the National Science Foundation of the United States.

Author Contributions: E.R.-M. and J.K.C.R. conceived and designed the experiments. E.R.-M., S.Z., and D.S.D. carried out experiments. E.R.-M. and I.S. wrote the manuscript. Z.F. performed the RNA-seq and associated bioinformatic analysis. All co-authors read and contributed to the preparation of the manuscript.

Conflicts of Interest: The authors declare no conflict of interest.

\section{References}

1. Klis, F.M.; Sosinska, G.J.; de Groot, P.W.; Brul, S. Covalently linked cell wall proteins of Candida albicans and their role in fitness and virulence. FEMS Yeast Res. 2009, 9, 1013-1028. [CrossRef] [PubMed]

2. Agrawal, G.K.; Jwa, N.S.; Lebrun, M.H.; Job, D.; Rakwal, R. Plant secretome: Unlocking secrets of the secreted proteins. Proteomics 2010, 10, 799-827. [CrossRef] [PubMed]

3. Sorgo, A.G.; Heilmann, C.J.; Brul, S.; de Koster, C.G.; Klis, F.M. Beyond the wall: Candida albicans secret(e)s to survive. FEMS Microbiol. Lett. 2013, 338, 10-17. [CrossRef] [PubMed]

4. Gupta, S.; Wardhan, V.; Kumar, A.; Rathi, D.; Pandey, A.; Chakraborty, S.; Chakraborty, N. Secretome analysis of chickpea reveals dynamic extracellular remodeling and identifies a Bet v1-like protein, CaRRP1 that participates in stress response. Sci. Rep. 2015, 5, 18427. [CrossRef] [PubMed]

5. Kim, K.-T.; Jeon, J.; Choi, J.; Cheong, K.; Song, H.; Choi, G.; Kang, S.; Lee, Y.-H. Kingdom-wide analysis of fungal small secreted proteins (SSPs) reveals their potential role in host association. Front. Plant Sci. 2016, 7, 186. [CrossRef] [PubMed]

6. Zielinska, D.F.; Gnad, F.; Schropp, K.; Wisniewski, J.R.; Mann, M. Mapping N-glycosylation sites across seven evolutionarily distant species reveals a divergent substrate proteome despite a common core machinery. Mol. Cell 2012, 46, 542-548. [CrossRef] [PubMed]

7. Meissner, F.; Scheltema, R.A.; Mollenkopf, H.J.; Mann, M. Direct proteomic quantification of the secretome of activated immune cells. Science 2013, 340, 475-478. [CrossRef] [PubMed]

8. Smeekens, J.M.; Xiao, H.; Wu, R. Global analysis of secreted proteins and glycoproteins in Saccharomyces cerevisiae. J. Proteome Res. 2017, 16, 1039-1049. [CrossRef] [PubMed]

9. Hervé, V.; Duruflé, H.; San Clemente, H.; Albenne, C.; Balliau, T.; Zivy, M.; Dunand, C.; Jamet, E. An enlarged cell wall proteome of Arabidopsis thaliana rosettes. Proteomics 2016, 16, 3183-3187. [CrossRef] [PubMed]

10. Rodríguez-Celma, J.; Ceballos-Laita, L.; Grusak, M.A.; Abadía, J.; López-Millán, A.-F. Plant fluid proteomics: Delving into the xylem sap, phloem sap and apoplastic fluid proteomes. Biochim. Biophys. Acta 2016, 1864, 991-1002. [CrossRef] [PubMed]

11. Calderan-Rodrigues, M.J.; Jamet, E.; Douché, T.; Bonassi, M.B.R.; Cataldi, T.R.; Fonseca, J.G.; San Clemente, H.; Pont-Lezica, R.; Labate, C.A. Cell wall proteome of sugarcane stems: Comparison of a destructive and a non-destructive extraction method showed differences in glycoside hydrolases and peroxidases. BMC Plant Biol. 2016, 16, 14. [CrossRef] [PubMed]

12. Nguyen-Kim, H.; San Clemente, H.; Balliau, T.; Zivy, M.; Dunand, C.; Albenne, C.; Jamet, E. Arabidopsis thatiana root cell wall proteomics: Increasing the proteome coverage using a combinatorial peptide ligand library and description of unexpected Hyp in peroxidase amino acid sequences. Proteomics 2016, 16, 491-503. [CrossRef] [PubMed]

13. Kim, S.G.; Wang, Y.; Lee, K.H.; Park, Z.Y.; Park, J.; Wu, J.; Kwon, S.J.; Lee, Y.H.; Agrawal, G.K.; Rakwal, R.; et al. In-depth insight into in vivo apoplastic secretome of rice-Magnaporthe oryzae interaction. J. Proteom. 2013, 78, 58-71. [CrossRef] [PubMed]

14. Gupta, R.; Lee, S.E.; Agrawal, G.K.; Rakwal, R.; Park, S.; Wang, Y.; Kim, S.T. Understanding the plant-pathogen interactions in the context of proteomics-generated apoplastic proteins inventory. Front. Plant Sci. 2015, 6, 352. [CrossRef] [PubMed] 
15. Lee, J.H.; Waffenschmidt, S.; Small, L.; Goodenough, U. Between-species analysis of short-repeat modules in cell wall and sex-related hydroxyproline-rich glycoproteins of Chlamydomonas. Plant Physiol. 2007, 144, 1813-1826. [CrossRef] [PubMed]

16. Baba, M.; Suzuki, I.; Shiraiwa, Y. Proteomic analysis of high- $\mathrm{CO}_{2}$-inducible extracellular proteins in the unicellular green alga, Chlamydomonas reinhardtii. Plant Cell Physiol. 2011, 52, 1302-1314. [CrossRef] [PubMed]

17. Mathieu-Rivet, E.; Scholz, M.; Arias, C.; Dardelle, F.; Schulze, S.; Le Mauff, F.; Teo, G.; Hochmal, A.K.; Blanco-Rivero, A.; Loutelier-Bourhis, C.; et al. Exploring the $N$-glycosylation pathway in Chlamydomonas reinhardtii unravels novel complex structures. Mol. Cell. Proteom. 2013, 12, 3160-3183. [CrossRef] [PubMed]

18. Voigt, J.; Stolarczyk, A.; Zych, M.; Malec, P.; Burczyk, J. The cell-wall glycoproteins of the green alga Scenedesmus obliquus. The predominant cell-wall polypeptide of Scenedesmus obliquus is related to the cell-wall glycoprotein gp3 of Chlamydomonas reinhardtii. Plant Sci. 2014, 215-216, 39-47. [CrossRef] [PubMed]

19. Roberts, K.; Grief, C.; Hills, G.J.; Shaw, P.J. Cell wall glycoproteins: Structure and function. J. Cell Sci. 1985, 2, 105-127. [CrossRef]

20. Stanley, M.S.; Perry, R.M.; Callow, J.A. Analysis of expressed sequence tags from the green alga Ulva linza (chlorophyta). J. Phycol. 2005, 41, 1219-1226. [CrossRef]

21. Merchant, S.S.; Prochnik, S.E.; Vallon, O.; Harris, E.H.; Karpowicz, S.J.; Witman, G.B. The Chlamydomonas genome reveals the evolution of key animal and plant functions. Science 2007, 318, 245-250. [CrossRef] [PubMed]

22. Schwarz, F.; Aebi, M. Mechanisms and principles of N-linked protein glycosylation. Curr. Opin. Struct. Biol. 2011, 21, 576-582. [CrossRef] [PubMed]

23. Varki, A. Evolutionary forces shaping the golgi glycosylation machinery: Why cell surface glycans are universal to living cells. Cold Spring Harb. Perspect. Biol. 2011, 3, a005462. [CrossRef] [PubMed]

24. Schiller, B.; Hykollari, A.; Yan, S.; Paschinger, K.; Wilson, I.B.H. Complicated N-linked glycans in simple organisms. Biol. Chem. 2012, 393, 661-673. [CrossRef] [PubMed]

25. Baiet, B.; Burel, C.; Saint-Jean, B.; Louvet, R.; Menu-Bouaouiche, L.; Kiefer-Meyer, M.C.; Mathieu-Rivet, E.; Lefebvre, T.; Castel, H.; Carlier, A.; et al. N-glycans of Phaeodactylum tricornutum diatom and functional characterization of its $N$-acetylglucosaminyltransferase I enzyme. J. Biol. Chem. 2011, 286, 6152-6164. [CrossRef] [PubMed]

26. Ford, K.L.; Zeng, W.; Heazlewood, J.L.; Bacic, A. Characterization of protein N-glycosylation by tandem mass spectrometry using complementary fragmentation techniques. Front. Plant Sci. 2015, 6. [CrossRef] [PubMed]

27. Levy-Ontman, O.; Arad, S.M.; Harvey, D.J.; Parsons, T.B.; Fairbanks, A.; Tekoah, Y. Unique N-glycan moieties of the 66-kDa cell wall glycoprotein from the red microalga Porphyridium sp. J. Biol. Chem. 2011, 286, 21340-21352. [CrossRef] [PubMed]

28. Colombino, L.F.; Bosmann, H.B.; McLean, R.J. Cell surface localization of the sialyltransferase ectoenzyme system during the Chlamydomonas mating reaction. Exp. Cell Res. 1978, 112, 25-30. [CrossRef]

29. Mamedov, T.; Yusibov, V. Green algae Chlamydomonas reinhardtii possess endogenous sialylated N-glycans. FEBS Open Biol. 2011, 1, 15-22. [CrossRef] [PubMed]

30. Ruiz-May, E.; Hucko, S.; Howe, K.J.; Zhang, S.; Sherwood, R.W.; Thannhauser, T.W.; Rose, J.K. A Comparative study of lectin affinity based plant $\mathrm{N}$-glycoproteome profiling using tomato fruit as a model. Mol. Cell. Proteom. 2014, 13, 566-579. [CrossRef] [PubMed]

31. Lewis, L.A.; McCourt, R.M. Green algae and the origin of land plants. Am. J. Bot. 2004, 91, 1535-1556. [CrossRef] [PubMed]

32. Becker, B.; Marin, B. Streptophyte algae and the origin of embryophytes. Ann. Bot. 2009, 103, 999-1004. [CrossRef] [PubMed]

33. Leliaert, F.; Smith, D.R.; Moreau, H.; Herron, M.D.; Verbruggen, H.; Delwiche, C.F.; De Clerck, O. Phylogeny and molecular evolution of the green algae. Crit. Rev. Plant Sci. 2012, 31, 1-46. [CrossRef]

34. Wodniok, S.; Brinkmann, H.; Glöckner, G.; Heidel, A.J.; Philippe, H.; Melkonian, M.; Becker, B. Origin of land plants: Do conjugating green algae hold the key? BMC Evol. Biol. 2011, 11, 104. [CrossRef] [PubMed]

35. Zhong, B.; Sun, L.; Penny, D. The origin of land plants: A phylogenomic perspective. Evol. Bioinform. 2015, 11, 137-141. [CrossRef] [PubMed] 
36. Timme, R.E.; Delwiche, C.F. Uncovering the evolutionary origin of plant molecular processes: Comparison of Coleochaete (Coleochaetales) and Spirogyra (Zygnematales) transcriptomes. BMC Plant Biol. 2010, 10, 96. [CrossRef] [PubMed]

37. Sørensen, I.; Pettolino, F.A.; Bacic, A.; Ralph, J.; Lu, F.; O’Neill, M.A.; Fei, Z.; Rose, J.K.; Domozych, D.S.; Willats, W.G. The charophycean green algae provide insights into the early origins of plant cell walls. Plant J. 2011, 68, 201-211. [CrossRef] [PubMed]

38. Hori, K.; Maruyama, F.; Fujisawa, T.; Togashi, T.; Yamamoto, N.; Seo, M.; Sato, S.; Yamada, T.; Mori, H.; Tajima, N.; et al. Klebsormidium flaccidum genome reveals primary factors for plant terrestrial adaptation. Nat. Commun. 2014, 5, 3978. [CrossRef] [PubMed]

39. Domozych, D.S.; Kort, S.; Benton, S.; Yu, T. The extracellular polymeric substance of the green alga Penium margaritaceum and its role in biofilm formation. Biofilms 2005, 2, 129-144. [CrossRef]

40. Domozych, D.S. Exopolymer production by the green alga Penium margaritaceum: Implication for biofilm residency. Int. J. Plant Sci. 2007, 168, 763-774. [CrossRef]

41. Domozych, D.S.; Serfis, A.; Kiemle, S.N.; Gretz, M.R. The structure and biochemistry of charophycean cell walls: I. Pectins of Penium margaritaceum. Protoplasma 2007, 230, 99-115. [CrossRef] [PubMed]

42. Domozych, D.S.; Brechka, B.; Britton, A.; Toso, M. Cell wall growth and modulation dynamics in a model unicellular green alga-Penium margaritaceum: Live cell labeling with monoclonal antibodies. J. Bot. 2011, 1-8. [CrossRef]

43. Eder, M.; Tenhaken, R.; Driouich, A.; Lutz-Meindl, U. Occurrence and characterization of arabinogalactan-like proteins and hemicelluloses in Micrasterias (Streptophyta). J. Phycol. 2008, 44, 1221-1234. [CrossRef] [PubMed]

44. Paerl, H.W.; Pinckney, J.L. A mini-review of microbial consortia: Their roles in aquatic production and biogeochemical cycling. Microb. Ecol. 1996, 31, 225-247. [CrossRef] [PubMed]

45. Ben-Ari, E.T. Not just slime: Beneath the slippery exterior of a microbial biofilm lies a remarkably organized community of organisms. BioScience 1999, 49, 689-695. [CrossRef]

46. Christensen, B.E. Physical and chemical properties of extracellular polysaccharides associated with biofilms and related systems. In Microbial Extracellular Polymeric Substances; Wingender, J., Neu, T.R., Flemming, H.C., Eds.; Springer: Berlin/Heidelberg, Germany, 1999; Chapter 8; pp. 143-154.

47. Flemming, H.C.; Wingender, J. The biofilm matrix. Nat. Rev. Microbiol. 2010, 8, 623-633. [CrossRef] [PubMed]

48. Sutherland, I.W. Biofilm exopolysaccharides: A strong and sticky framework. Microbiology 2001, 147, 3-9. [CrossRef] [PubMed]

49. Sutherland, I.W. The biofilm matrix: An immobilized but dynamic microbial environment. Trends Microbiol. 2001, 9, 222-227. [CrossRef]

50. Flemming, H.C.; Wingender, J. Relevance of microbial extracellular polymeric substances (EPSs)—Part I: Structural and ecological aspects. Water Sci. Technol. 2001, 43, 1-8. [PubMed]

51. Niklas, K.J. The cell walls that bind the tree of life. BioScience 2004, 54, 831-841. [CrossRef]

52. Elster, J.; Lukavsky, J.; Harding, K.; Benson, E.E.; Day, J.G. Deployment of the encapsulation-dehydration protocol to cryopreserve polar microalgae held at the Czech Republic Academy of Sciences Institute of Botany. CryoLetters 2008, 29, 27-28. [PubMed]

53. Sørensen, I.; Fei, Z.; Andreas, A.; Willats, W.G.T.; Domozych, D.S.; Rose, J.K.C. Stable transformation and reverse genetic analysis of Penium margaritaceum: A platform for studies of charophyte green algae, the immediate ancestors of land plants. Plant J. 2014, 77, 339-351. [CrossRef] [PubMed]

54. Varki, A.; Cummings, R.D.; Esko, J.D.; Freeze, H.H.; Stanley, P.; Marth, J.D.; Bertozzi, C.R.; Hart, G.W.; Etzler, M.E. Symbol nomenclature for glycan representation. Proteomics 2009, 9, 5398-5399. [CrossRef] [PubMed]

55. Zhang, Y.; Giboulot, A.; Zivy, M.; Valot, B.; Jamet, E.; Albenne, C. Combining various strategies to increase the coverage of the plant cell wall glycoproteome. Phytochemistry 2010, 72, 1109-1123. [CrossRef] [PubMed]

56. Lombard, J. The multiple evolutionary origins of the eukaryotic N-glycosylation pathway. Biol. Direct 2016, 11, 36. [CrossRef] [PubMed]

57. Domozych, D.; Lietz, A.; Patten, M.; Singer, E.; Tinaz, B.; Raimundo, S.C. Imaging the dynamics of cell wall polymer deposition in the unicellular model plant, Penium margaritaceum. In Light Microscopy: Methods and Protocols; Methods in Molecular Biology; Markaki, Y., Hartmann, H., Eds.; Springer: New York, NY, USA, 2017; Volume 1563, pp. 91-105. 
58. Katoh, H.; Ikeuchi, M. Targeted disruption of psbX and biochemical characterization of photosystem II complex in the thermophilic cyanobacterium Synechococcus elongatus. Plant Cell Physiol. 2001, 42, 179-188. [CrossRef] [PubMed]

59. Catalá, C.; Howe, K.J.; Hucko, S.; Rose, J.K.; Thannhauser, T.W. Towards characterization of the glycoproteome of tomato (Solanum lycopersicum) fruit using concanavalin A lectin affinity chromatography and LC-MALDI-MS/MS analysis. Proteomics 2011, 11, 1530-1544. [CrossRef] [PubMed]

60. Laemmli, U.K. Cleavage of structural proteins during the assembly of the head of bacteriophage T4. Nature 1970, 227, 680-685. [CrossRef] [PubMed]

61. Zhang, S.; Sherwood, R.W.; Yang, Y.; Fish, T.; Chen, W.; McCardle, J.A.; Jones, R.M.; Yusibov, V.; May, E.R.; Rose, J.K.; et al. Comparative characterization of the glycosylation profiles of an influenza hemagglutinin produced in plant and insect hosts. Proteomics 2012, 12, 1269-1288. [CrossRef] [PubMed]

62. Jamet, E.; Canut, H.; Boudart, G.; Pont-Lezica, R.F. Cell wall proteins: A new insight through proteomics. Trends Plant Sci. 2006, 11, 33-39. [CrossRef] [PubMed]

63. Petersen, T.N.; Brunak, S.; von Heijne, G.; Nielsen, H. SignalP 4.0: Discriminating signal peptides from transmembrane regions. Nat. Methods 2011, 8, 785-786. [CrossRef] [PubMed]

64. Nakai, K.; Horton, P. PSORT: A program for detecting sorting signals in proteins and predicting their subcellular localization. Trends Biochem. Sci. 1999, 24, 34-36. [CrossRef]

65. Emanuelsson, O.; Brunak, S.; von Heijne, G.; Nielsen, H. Locating proteins in the cell using TargetP, SignalP and related tools. Nat. Protoc. 2007, 2, 953-971. [CrossRef] [PubMed]

66. Tardif, M.; Atteia, A.; Specht, M.; Cogne, G.; Rolland, N.; Brugiere, S.; Hippler, M.; Ferro, M.; Bruley, C.; Peltier, G.; et al. PredAlgo: A new subcellular localization prediction tool dedicated to green algae. Mol. Biol. Evol. 2012, 29, 3625-3639. [CrossRef] [PubMed]

67. Krogh, A.; Larsson, B.; von Heijne, G.; Sonnhammer, E.L. Predicting transmembrane protein topology with a hidden Markov model: Application to complete genomes. J. Mol. Biol. 2001, 305, 567-580. [CrossRef] [PubMed]

68. Hirokawa, T.; Boon-Chieng, S.; Mitaku, S. SOSUI: Classification and secondary structure prediction system for membrane proteins. Bioinformatics 1998, 14, 378-379. [CrossRef] [PubMed]

69. Varki, A.; Cummings, R.D.; Esko, J.D.; Stanley, P.; Hart, G.; Aebi, M.; Darvill, A.; Kinoshita, T.; Packer, N.H.; Prestegard, J.J.; et al. Essentials of Glycobiology; Cold Spring Harbor Laboratory Press: Cold Spring Harbor, NY, USA, 2015.

70. Minic, Z.; Jamet, E.; Negroni, L.; Arsene der Garabedian, P.; Zivy, M.; Jouanin, L. A sub-proteome of Arabidopsis thaliana mature stems trapped on Concanavalin A is enriched in cell wall glycoside hydrolases. J. Exp. Bot. 2007, 58, 2503-2512. [CrossRef] [PubMed]

71. Martiniere, A.; Gayral, P.; Hawes, C.; Runions, J. Building bridges: Formin1 of Arabidopsis forms a connection between the cell wall and the actin cytoskeleton. Plant J. 2011, 66, 354-365. [CrossRef] [PubMed]

72. Held, M.A.; Tan, L.; Kamyab, A.; Hare, M.; Shpak, E.; Kieliszewski, M.J. Di-isodityrosine is the intermolecular cross-link of isodityrosine-rich extensin analogs cross-linked in vitro. J. Biol. Chem. 2004, 279, 55474-55482. [CrossRef] [PubMed]

73. Ellis, M.; Egelund, J.; Schultz, C.J.; Bacic, A. Arabinogalactan-proteins: Key regulators at the cell surface? Plant Physiol. 2010, 153, 403-419. [CrossRef] [PubMed]

74. Tan, L.; Eberhard, S.; Pattathil, S.; Warder, C.; Glushka, J.; Yuan, C.H.; Hao, Z.Y.; Zhu, X.; Avci, U.; Miller, J.S.; et al. An arabidopsis cell wall proteoglycan consists of pectin and arabinoxylan covalently linked to an arabinogalactan protein. Plant Cell 2013, 25, 270-287. [CrossRef] [PubMed]

75. Knox, J.P.; Linstead, P.J.; Peart, J.; Cooper, C.; Roberts, K. Developmentally regulated epitopes of cell-surface arabinogalactan proteins and their relation to root-tissue pattern-formation. Plant J. 1991, 1, 317-326. [CrossRef] [PubMed]

76. Smallwood, M.; Beven, A.; Donovan, N.; Neill, S.J.; Peart, J.; Roberts, K.; Knox, J.P. Localization of cell-wall proteins in relation to the developmental anatomy of the carrot root Apex. Plant J. 1994, 5, 237-246. [CrossRef]

77. Yates, E.A.; Knox, J.P. Investigations into the occurrence of plant-cell surface epitopes in exudate gums. Carbohydr. Polym. 1994, 24, 281-286. [CrossRef] 
78. Yates, E.A.; Valdor, J.F.; Haslam, S.M.; Morris, H.R.; Dell, A.; Mackie, W.; Knox, J.P. Characterization of carbohydrate structural features recognized by anti-arabinogalactan-protein monoclonal antibodies. Glycobiology 1996, 6, 131-139. [CrossRef] [PubMed]

79. Showalter, A.M. Arabinogalactan-proteins: Structure, expression and function. Cell. Mol. Life Sci. 2001, 58, 1399-1417. [CrossRef] [PubMed]

80. Laine, A.C.; Gomord, V.; Faye, L. Xylose-specific antibodies as markers of subcompartmentation of terminal glycosylation in the golgi apparatus of sycamore cells. FEBS Lett. 1991, 295, 179-184. [CrossRef]

81. Velasquez, S.M.; Ricardi, M.M.; Dorosz, J.G.; Fernandez, P.V.; Nadra, A.D.; Pol-Fachin, L.; Egelund, J.; Gille, S.; Harholt, J.; Ciancia, M.; et al. O-Glycosylated cell wall proteins are essential in root hair growth. Science 2011, 332, 1401-1403. [CrossRef] [PubMed]

82. Champagne, A.; Boutry, M. Proteomics of nonmodel plant species. Proteomics 2013, 13, 663-673. [CrossRef] [PubMed]

83. Lopez-Casado, G.; Covey, P.A.; Bedinger, P.A.; Mueller, L.A.; Thannhauser, T.W.; Zhang, S.; Fei, Z.; Giovannoni, J.J.; Rose, J.K. Enabling proteomic studies with RNA-Seq: The proteome of tomato pollen as a test case. Proteomics 2012, 12, 761-774. [CrossRef] [PubMed]

84. Witters, E.; Laukens, K.; Deckers, P.; Van Dongen, W.; Esmans, E.; Van Onckelen, H. Fast liquid chromatography coupled to electrospray tandem mass spectrometry peptide sequencing for cross-species protein identification. Rapid Commun. Mass Spectrom. 2003, 17, 2188-2194. [CrossRef] [PubMed]

85. Bräutigam, A.; Shrestha, R.P.; Whitten, D.; Wilkerson, C.G.; Carr, K.M.; Froehlich, J.E.; Weber, A.P. Low-coverage massively parallel pyrosequencing of cDNAs enables proteomics in non-model species: Comparison of a species-specific database generated by pyrosequencing with databases from related species for proteome analysis of pea chloroplast envelopes. J. Biotechnol. 2008, 136, 44-53. [CrossRef] [PubMed]

86. Wright, J.C.; Beynon, R.J.; Hubbard, S.J. Cross species proteomics. Methods Mol. Biol. 2010, 604, $123-135$. [PubMed]

87. Friso, G.; van Wijk, K.J. Posttranslational protein modifications in plant metabolism. Plant Physiol. 2015, 169, 1469-1487. [PubMed]

88. Neubert, P.; Halim, A.; Zauser, M.; Essig, A.; Joshi, H.J.; Zatorska, E.; Larsen, I.S.B.; Loibl, M.; Castells-Ballester, J.; Aebi, M.; et al. Mapping the O-Mannose glycoproteome in Saccharomyces cerevisiae. Mol. Cell. Proteom. 2016, 15, 1323-1337. [CrossRef] [PubMed]

89. Li, Y.Q.; Chen, F.; Linskens, H.F.; Cresti, M. Distribution of unesterified and esterified pectins in cell walls of pollen tubes of flowering plants. Sex. Plant Reprod. 1994, 7, 145-152. [CrossRef]

90. Li, Y.Q.; Zhang, H.Q.; Pierson, E.S.; Huang, F.Y.; Linskens, H.F.; Hepler, P.K.; Cresti, M. Enforced growth-rate fluctuation causes pectin ring formation in the cell wall of Lilium longiflorum pollen tubes. Planta 1996, 200, 41-49. [CrossRef]

91. Nuñez, A.; Fishman, M.L.; Fortis, L.L.; Cooke, P.H.; Hotchkiss, A.T., Jr. Identification of extensin protein associated with sugar beet pectin. J. Agric. Food Chem. 2009, 57, 10951-10958. [CrossRef] [PubMed]

92. MacMillan, C.P.; Mansfield, S.D.; Stachurski, Z.H.; Evans, R.; Southerton, S.G. Fasciclin-like arabinogalactan proteins: Specialization for stem biomechanics and cell wall architecture in Arabidopsis and Eucalyptus. Plant J. 2010, 62, 689-703. [CrossRef] [PubMed]

93. Johnson, K.L.; Kibble, N.A.; Bacic, A.; Schultz, C.J. A fasciclin-like arabinogalactan-protein (FLA) mutant of Arabidopsis thaliana, fla1, shows defects in shoot regeneration. PLoS ONE 2011, 6, e25154. [CrossRef] [PubMed]

94. Tan, L.; Showalter, A.M.; Egelund, J.; Hernandez-Sanchez, A.; Doblin, M.S.; Bacic, A. Arabinogalactan-proteins and the research challenges for these enigmatic plant cell surface proteoglycans. Front Plant Sci. 2012, 3, 140. [CrossRef] [PubMed]

95. Huang, G.Q.; Gong, S.; Xu, W.L.; Li, W.; Li, P.; Zhang, C.J.; Li, D.D.; Zheng, Y.; Li, F.G.; Li, X.B. A fasciclin-like arabinogalactan protein, GhFLA1, is involved in fiber initiation and elongation of cotton. Plant Physiol. 2013, 161, 1278-1290. [CrossRef] [PubMed]

96. Kiemle, S.N.; Domozych, D.S.; Gretz, M.R. The extracellular polymeric substances of desmids (Conjugatophyceae, Streptophyta): Chemistry, structural analyses and implications in wetland biofilms. Phycologia 2007, 46, 617-627. [CrossRef]

97. Van Gisbergen, P.A.; Li, M.; Wu, S.Z.; Bezanilla, M. Class II formin targeting to the cell cortex by binding $\mathrm{PI}(3,5) \mathrm{P}(2)$ is essential for polarized growth. J. Cell Biol. 2012, 198, 235-250. [CrossRef] [PubMed] 
98. Zhang, S.; Liu, C.; Wang, J.; Ren, Z.; Staiger, C.J.; Ren, H. A processive Arabidopsis formin modulates actin filament dynamics in association with profilin. Mol. Plant 2016, 9, 900-910. [CrossRef] [PubMed]

99. Balshüsemann, D.; Jaenicke, L. The oligosaccharides of the glycoprotein pheromone of Volvox-Carteri F Nagariensis Iyengar (Chlorophyceae). Eur. J. Biochem. 1990, 192, 231-237. [CrossRef] [PubMed]

100. Chalovich, J.M.; Eisenberg, E. High-sensitivity analytical approaches for the structural characterization of glycoproteins. Chem. Rev. 2005, 257, 2432-2437.

(c) 2018 by the authors. Licensee MDPI, Basel, Switzerland. This article is an open access article distributed under the terms and conditions of the Creative Commons Attribution (CC BY) license (http:/ / creativecommons.org/licenses/by/4.0/). 